\title{
Metabolic shifts in the Antarctic fish Notothenia rossii in response to rising temperature and $\mathrm{PCO}_{2}$
}

\author{
Anneli Strobel $^{1 *}$, Swaantje Bennecke ${ }^{1}$, Elettra Leo ${ }^{1,2}$, Katja Mintenbeck$^{1}$, Hans O Pörtner ${ }^{1}$ and Felix C Mark
}

\begin{abstract}
Introduction: Ongoing ocean warming and acidification increasingly affect marine ecosystems, in particular around the Antarctic Peninsula. Yet little is known about the capability of Antarctic notothenioid fish to cope with rising temperature in acidifying seawater. While the whole animal level is expected to be more sensitive towards hypercapnia and temperature, the basis of thermal tolerance is set at the cellular level, with a putative key role for mitochondria. This study therefore investigates the physiological responses of the Antarctic Notothenia rossii after long-term acclimation to increased temperatures $\left(7^{\circ} \mathrm{C}\right)$ and elevated $P \mathrm{CO}_{2}\left(0.2 \mathrm{kPa} \mathrm{CO}_{2}\right)$ at different levels of physiological organisation.

Results: For an integrated picture, we analysed the acclimation capacities of $N$. rossii by measuring routine metabolic rate (RMR), mitochondrial capacities (state III respiration) as well as intra- and extracellular acid-base status during acute thermal challenges and after long-term acclimation to changing temperature and hypercapnia. RMR was partially compensated during warm- acclimation (decreased below the rate observed after acute warming), while elevated $\mathrm{PCO}_{2}$ had no effect on cold or warm acclimated RMR. Mitochondrial state III respiration was unaffected by temperature acclimation but depressed in cold and warm hypercapnia-acclimated fish. In both cold- and warm-exposed $\mathrm{N}$. rossii, hypercapnia acclimation resulted in a shift of extracellular $\mathrm{pH}\left(\mathrm{pH}_{\mathrm{e}}\right)$ towards more alkaline values. A similar overcompensation was visible in muscle intracellular $\mathrm{pH}\left(\mathrm{pH}_{\mathrm{i}}\right)$. $\mathrm{pH}_{\mathrm{i}}$ in liver displayed a slight acidosis after warm normo- or hypercapnia acclimation, nevertheless, long-term exposure to higher $\mathrm{PCO}_{2}$ was compensated for by intracellular bicarbonate accumulation.

Conclusion: The partial warm compensation in whole animal metabolic rate indicates beginning limitations in tissue oxygen supply after warm-acclimation of $N$. rossii. Compensatory mechanisms of the reduced mitochondrial capacities under chronic hypercapnia may include a new metabolic equilibrium to meet the elevated energy demand for acid-base regulation. New set points of acid-base regulation under hypercapnia, visible at the systemic and intracellular level, indicate that $\mathrm{N}$. rossii can at least in part acclimate to ocean warming and acidification. It remains open whether the reduced capacities of mitochondrial energy metabolism are adaptive or would impair population fitness over longer timescales under chronically elevated temperature and $\mathrm{PCO}_{2}$.
\end{abstract}

Keywords: Notothenioid, Oxygen consumption, Routine metabolic rate, Extracellular $\mathrm{pH}\left(\mathrm{pH}_{\mathrm{e}}\right)$, Intracellular $\mathrm{pH}\left(\mathrm{pH}_{\mathrm{i}}\right)$, Mitochondrial respiration, Acclimation, Acid-base

\footnotetext{
* Correspondence: anneli.strobel@awi.de

${ }^{1}$ Alfred Wegener Institute for Polar and Marine Research, Integrative

Ecophysiology, Am Handelshafen 12, D-27570 Bremerhaven, Germany

Full list of author information is available at the end of the article
} 


\section{Introduction}

Recent studies have demonstrated warming of the worlds' oceans, and the Antarctic Peninsula also experiences a continuous increase in temperature [1-6]. Additionally, anthropogenic $\mathrm{CO}_{2}$-emissions accumulate in the atmosphere and the oceans [7] and result in a decrease in seawater $\mathrm{pH}$ (ocean acidification) [8-10]. Both ocean warming and acidification exert their specific effects on the marine fauna. Studies identifying the capacity of Antarctic fish to cope with thermal challenges [11-17] contributed to the concept of oxygen and capacity limited thermal tolerance, which explains the limits of thermal tolerance through limitations in tissue functional capacity and the associated oxygen limitation at high and low temperatures $[13,18,19]$.

Changes in seawater temperature particularly affect cold stenothermal organisms, which generally possess extremely slow metabolic rates and poor acclimation capacities, when compared to temperate species [20,21]. While temperate ectothermic vertebrate and invertebrate species are apparently capable of shifting their temperature limits by acclimation [22], this feature and the potential interaction between effects of warming and increasing ocean acidification have been insufficiently explored in Antarctic fauna [11,23-25]. As stenothermal Antarctic fish are assumed to perform well only within their narrow environmental temperature range $[15,26]$, the question arises whether these species can acclimate to increasing temperature and rising ocean $\mathrm{PCO}_{2}$.

Whole animal oxygen consumption rates reflect the energy demand of the organism as the sum of all physiological costs, including ion and acid-base regulation [20]. Under changing abiotic conditions, the rate of all or some of these processes may change, causing an increased or decreased overall demand for ATP. Therefore, the functional properties of mitochondria as the sites of energy (ATP) production may play a key role in shaping whole organism thermal tolerance and limits of aerobic metabolism $[13,27,28]$. However, the studies on mitochondrial respiration and capacities of Antarctic invertebrates [29,30] and fish [12,28,31-33] have so far not addressed changes in mitochondrial respiration after long-term acclimation to increased temperature or $\mathrm{PCO}_{2}$.

Increasing seawater $\mathrm{PCO}_{2}$ levels are hypothesized to narrow an organism's thermal windows, possibly by limiting the ability to compensate for changes in acid-base status at thermal extremes [34-36]. Changes in acid-base status affect whole organism, cellular and molecular functions. Findings in teleost fish range from high compensatory abilities for rising seawater $\mathrm{PCO}_{2}$ [37-39], to incomplete compensation with a long-term reduction in $\mathrm{pH}_{\mathrm{e}}$ [40].

Less is known about the response of intracellular $\mathrm{pH}$ $\left(\mathrm{pH}_{\mathrm{i}}\right)$ to changing temperature or hypercapnia in both marine vertebrates and invertebrates [41-44]. The intracellular proton buffering capacity of vertebrates is found to vary markedly between animal species, tissue type and aerobic capacity [45-48]. Especially studies on intracellular acidbase status in Antarctic fish are scarce [49].

The Antarctic fish species $N$. rossii is an abundant member of coastal Antarctic communities [50-52] and is widely distributed between $45^{\circ}$ and $\sim 62^{\circ} \mathrm{S}$ [53,54]. Water temperatures around the Antarctic Peninsula, e.g. in Potter Cove at King George Island, range from $-2^{\circ} \mathrm{C}$ in winter to $2^{\circ} \mathrm{C}$ in summer [55]. N. rossii is adapted to this narrow thermal range and may display a limited resistance and acclimation capacity to warming compared to more eurythermal fish species.

The aim of this paper is to investigate the acclimation capacities of relevant components in aerobic metabolism of the Antarctic notothenioid N. rossii at increased seawater temperature and $\mathrm{PCO}_{2}$. In an integrative approach, we investigated acclimation to warming $\left(7^{\circ} \mathrm{C}\right)$ and hypercapnia $\left(0.2 \mathrm{kPa} \mathrm{CO}_{2}\right)$ at different organisational levels, the whole animal, extracellular (blood) and intracellular, and the mitochondrial level. We exposed the animals to various abiotic conditions and then focused on changes in the fish's condition and haematological parameters, and on oxygen consumption as a measure of routine metabolic rate (acute and after long-term acclimation). As a next step, we analysed mitochondrial acclimation and adaptation capacities (mitochondrial state III respiration, cytochrome c oxidase activity) as indicators of the plasticity of whole animal metabolic rate. Finally, we determined extraand intracellular acid-base parameters in $N$. rossii as a measure of acid-base regulation patterns and capacities, and related them to the findings of reduced mitochondrial capacities under hypercapnia.

\section{Material and methods}

\section{Animal capture and acclimation}

Demersal marbled rockcod, $N$. rossii, were caught in December 2009 in Potter Cove, King George Island, Antarctic Peninsula $\left(62^{\circ} 14^{\prime} \mathrm{S} ; 058^{\circ} 41^{\prime} \mathrm{W}\right)$ during the Antarctic summer season (seawater temperature $0.8^{\circ} \pm 0.9^{\circ}$ C, salinity $33.5 \pm 0.2 \mathrm{psu}$ ). Fish were collected using baited traps (length $124 \mathrm{~cm}$, width $64 \mathrm{~cm}$, height 56 $\mathrm{cm}$, mesh size $25 \mathrm{~mm}$ ) and trammel nets (length 15 $\mathrm{m}$, inner mesh $25 \mathrm{~mm}$ ).

Animals were reared and acclimated in the aquaria facilities at Dallmann Laboratory, Carlini Station (formerly Jubany Station, King George Island) with direct seawater supply from the cove, under natural light conditions. Following the Intergovernmental Panel on Climate Change's "business-as-usual" scenario, atmospheric $\mathrm{CO}_{2}$ concentrations may exceed $0.2 \mathrm{kPa}$ by the year 2200 $[8,56]$. Therefore, we chose $0.2 \mathrm{kPa} \mathrm{CO}_{2}$ for our hypercapnia acclimation of $N$. rossii. For acclimation, animals 
were randomly selected and acclimated to $1^{\circ} \mathrm{C}, 0.04 \mathrm{kPa}$ $\mathrm{CO}_{2}$ (control group, $n=9$, mass $155-804 \mathrm{~g}$; total length 25-39.4 cm), $1^{\circ} \mathrm{C}, 0.2 \mathrm{kPa} \mathrm{CO}$ (cold hypercapnic group, $n=10$, mass $144-510 \mathrm{~g}$; total length $23.8-32.8 \mathrm{~cm}$ ), $7^{\circ} \mathrm{C}$, $0.04 \mathrm{kPa} \mathrm{CO}_{2}$ (warm normocapnic group, $n=5$, mass 151-412 g; total length 23.6-33.9 cm) and $7^{\circ} \mathrm{C}, 0.2 \mathrm{kPa}$ $\mathrm{CO}_{2}$ (warm hypercapnic group, $n=10$, mass 137-504 g; total length $21.4-31.3 \mathrm{~cm}$ ). Animals were fed to satiation twice per week with chopped fish muscle and snails.

For all acclimations, seawater temperature (from $1^{\circ}$ to $7^{\circ} \mathrm{C}$ ) and $\mathrm{PCO}_{2}$ (from $0.04 \mathrm{kPa} \mathrm{CO}$ to $0.2 \mathrm{kPa} \mathrm{CO}$ ) were both increased stepwise $\left(1^{\circ} \mathrm{C} / 4\right.$ hours; $0.01 \mathrm{kPa}$ $\mathrm{CO}_{2} / \mathrm{h}$ ) over 24 hours. Total acclimation time was 2936 days. Experimental animals were acclimated in wellaerated ( $>95 \% \mathrm{O}_{2}$ saturation), 150 liter tanks, fed by an additional 150 liter header tank. This header tank was used for a daily water exchange of 150 liter to avoid alteration of the conditions in the acclimation tanks. For the warm normocapnia/ hypercapnia acclimations, temperature was kept constant using a $250 \mathrm{~W}$ heating element (Jaeger, EHEIM GmbH, Germany), controlled by a Temperature Controller TMP1380 (iSiTEC GmbH, Germany). For the cold/ warm hypercapnia acclimations, higher $\mathrm{PCO}_{2}$ was regulated by an iks aquastar system (iks ComputerSysteme $\mathrm{GmbH}$, Germany). The system maintained constant $\mathrm{pH}$ (accuracy $\pm 0.05 \mathrm{pH}$ units) by controlling a solenoid valve (Aqua Medic $\mathrm{GmbH}$, Germany), which bubbles the acclimation tanks with pure $\mathrm{CO}_{2}$. Specific seawater conditions are given in Table 1. pH of all acclimation systems was measured daily with a WTW 340i pH meter (WTW, Germany. Electrode: WTW SenTix HWS) and calibrated daily with NBS (WTW, Germany) buffer. Total $\mathrm{CO}_{2}\left(\mathrm{C}_{\mathrm{CO} 2}\right)$ in the seawater was determined with a carbon dioxide analyser (Corning 965, CIBA, Corning Diagnostics, England). Seawater carbonate chemistry was calculated with the measured $\mathrm{pH}_{\mathrm{NBS}}$ and $\mathrm{C}_{\mathrm{CO} 2}$ using the CO2sys software [57]. All experiments were conducted at Dallmann Laboratory (Carlini Station), King George Island, Antarctic Peninsula.

\section{Routine metabolic rate}

Routine metabolic rate (RMR) of $N$. rossii (control/ after acute temperature elevation/ long-term acclimated) was measured via intermittent-flow respirometry. Following Johnston et al. [58], fish were not fed for 10 days prior to the respiration experiments. After the acclimation period, each fish was placed in a 3500 to $4400 \mathrm{ml}$ nontransparent, cylindrical respirometer placed within a 150 liter tank under acclimation conditions. Individuals were allowed to recover within the respiration chamber for 24 hours, a period considered appropriate to overcome the effect of any handling stress [58]. A constant, circulating water flow in the respirometer was generated by an aquarium pump. In the intermittentflow system, water exchange between chamber and ambient water was interrupted every $30 \mathrm{~min}$ for 15 or $30 \mathrm{~min}$ to measure oxygen depletion $\left(\max .10 \% \mathrm{O}_{2}\right.$ ) by the fish within the chamber, then oxygen concentration was replenished to $100 \%$ by flush pumps. Oxygen concentration within the chamber was detected once per minute using a FiBox2 (PreSens - Precision Sensing GmbH, Germany) oxygen meter. The device was calibrated before each measurement in well-aerated seawater at the respective acclimation temperature, calibration at zero oxygen was conducted in nitrogenbubbled seawater.

In three individuals of $N$. rossii, oxygen consumption was measured before and after acute temperature increase. The same experimental setup as described above was used. After 24 hours of recovery, RMR was recorded for 24 hours under control conditions $\left(1^{\circ} \mathrm{C}\right)$, then temperature was increased continuously by $1^{\circ} \mathrm{C}$ per hour up to $7^{\circ} \mathrm{C}$. RMR was recorded at the beginning and at the end $\left(7^{\circ} \mathrm{C}\right)$ of the acute warming period. Mean RMR were calculated over 24 hours, and thus represent resting metabolism including spontaneous activity. Blank measurements of bacterial respiration in the respirometer were carried out for each acclimation group, values for RMR were corrected accordingly.

Table 1 Seawater physiochemical conditions of the control conditions and different warm/ hypercapnia acclimations of N. rossii at Carlini station

\begin{tabular}{|c|c|c|c|c|}
\hline Conditions & $\frac{\text { Control }}{\left(1^{\circ} \mathrm{C}, 0.04 \mathrm{kPa} \mathrm{CO}\right)_{2}}$ & $\frac{\text { Warm normocapnia }}{\left(7^{\circ} \mathrm{C}, 0.04 \mathrm{kPa} \mathrm{CO} 2\right)}$ & $\frac{\text { Cold hypercapnia }}{\left.\left(1^{\circ} \mathrm{C}, 0.2 \mathrm{kPa} \mathrm{CO}\right)_{2}\right)}$ & $\frac{\text { Warm hypercapnia }}{\left(7^{\circ} \mathrm{C}, 0.2 \mathrm{kPa} \mathrm{CO} 2\right)}$ \\
\hline $\mathrm{pH}$ & $8.250 \pm 0.015$ & $7.914 \pm 0.016$ & $7.455 \pm 0.018$ & $7.493 \pm 0.006$ \\
\hline$P_{\mathrm{CO} 2}(\mu \mathrm{atm})$ & $356.72 \pm 18.26$ & $461.43 \pm 13.69$ & $2179.04 \pm 54.50$ & $2018.55 \pm 26.93$ \\
\hline$P_{\mathrm{CO} 2}(\mathrm{kPa})$ & $0.037 \pm 0.002$ & $0.048 \pm 0.001$ & $0.225 \pm 0.006$ & $0.208 \pm 0.003$ \\
\hline $\mathrm{DIC}(\mathrm{mmol} / \mathrm{kgSW})$ & $2595.00 \pm 118.66$ & $1942.50 \pm 26.39$ & $2401.81 \pm 5.58$ & $2369.44 \pm 2.04$ \\
\hline $\mathrm{HCO}_{3}-(\mathrm{mmol} / \mathrm{kgSW})$ & $2429.78 \pm 110.06$ & $1839.93 \pm 26.00$ & $2254.02 \pm 3.54$ & $2241.68 \pm 1.06$ \\
\hline $\mathrm{T}\left({ }^{\circ} \mathrm{C}\right)$ & $1.45 \pm 0.09$ & $7.25 \pm 0.07$ & $1.36 \pm 0.17$ & $6.88 \pm 0.063$ \\
\hline S (psu) & $32.47 \pm 0.35$ & $32.75 \pm 0.21$ & $32.77 \pm 0.29$ & $32.63 \pm 0.26$ \\
\hline duration (weeks) & 1 & 4 & 4 & 4 \\
\hline
\end{tabular}




\section{Animal condition, sampling and haematological parameters}

After measurement of RMR and at the end of the acclimation period, specimens of $N$. rossii were anesthesized with $0.5 \mathrm{~g} / \mathrm{l}$ tricaine methano- sulphonate (MS 222). Blood was taken with a syringe from the caudal vein, the liver was taken for mitochondrial isolation. Parts of liver and muscle samples were immediately freeze-clamped and frozen in liquid nitrogen for $\mathrm{pH}_{\mathrm{i}}$ analysis, as described by Pörtner [47]. Afterwards, individuals were killed by a spinal cut behind the head plates. The work was carried out according to the ethics and guidelines of German law. Experiments had been approved according to $\$ 8$ animal welfare act $(18.05 .2006 ; 8081$. I p. 1207) by the veterinary inspection office, Bahnhofsplatz 29, 28195 Bremen, Germany, under the permit number Az.: 52227-11/02-00 (93) on January 15th, 2008 (permit valid until Jan 14th 2012).

Fulton's condition factor (CF) of N. rossii was calculated according to the formula [59]:

$$
\mathrm{CF}=\text { animal weight }[\mathrm{g}] \times 100 / \text { standard length }[\mathrm{cm}]^{3}
$$

The hepatosomatic index (HSI) was determined by

$$
\text { HSI = liver weight }[\mathrm{g}] / \text { total weight }[\mathrm{g}] \times 100
$$

The haematocrit of $N$. rossii was estimated in a blood subsample using a haematocrit centrifuge (Compur Microspin, Bayer Diagnostics Mfg. Ltd., Microspin, Ireland). Lactate concentration was measured with an Accutrend $^{\circledR}$ Lactate tester (Roche Diagnostics $\mathrm{GmbH}$, Germany). Osmolarity of the serum was measured after centrifugation of the blood for $10 \mathrm{~min}$ at $2000 \mathrm{~g}$. For the measurement, a Vapour Pressure Osmometer 5500 (Wescor Inc., USA) was used.

\section{Isolation of liver mitochondria and mitochondrial oxygen consumption measurements}

Immediately after excision, the liver was rinsed and total liver weight was determined before a subsample of liver tissue was taken, weighed and rinsed with $5 \mathrm{ml} / \mathrm{g}$ icecold isolation buffer containing $80 \mathrm{mM}$ sucrose, $85 \mathrm{mM}$ $\mathrm{KCl}, 5 \mathrm{mM}$ EGTA, $5 \mathrm{mM}$ EDTA, $50 \mathrm{mM}$ HEPES and 1\% $\mathrm{w} / \mathrm{v}$ bovine serum albumin (BSA, fatty acid free) ( $\mathrm{pH} 7.1$ at $20^{\circ} \mathrm{C}$ ). The liver tissue was then finely minced with scissors, suspended in 10 volumes ice-cold isolation buffer, and then put into a $30 \mathrm{ml}$ Potter-Elvehjem glass homogenizer (VWR International, Germany) and slowly homogenised with three strokes at 80 revolutions/ minute. The homogenate was centrifuged $\left(600 \mathrm{~g}, 10 \mathrm{~min} ., 0^{\circ} \mathrm{C}\right)$, the supernatant collected and the pellet vigorously resuspended by vortexing in isolation buffer and centrifuged for a second time. Supernatants were then combined and centrifuged for $10 \mathrm{~min}$ at $11.000 \mathrm{~g}\left(0^{\circ} \mathrm{C}\right)$. The supernatant was discarded, any remaining droplets of fat removed with a cotton swab and the pellet resuspended in isolation buffer and centrifuged again. As a last step, supernatant was discarded again, and the pellet was resuspended in ice-cold mitochondria assay

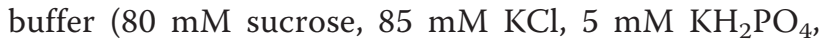
$50 \mathrm{mM}$ HEPES, 1\% w/v BSA (fatty acid free), $\mathrm{pH} 7,1$ at $20^{\circ} \mathrm{C}$ ) at $1 \mathrm{ml} / \mathrm{g}$ initial liver weight. This mitochondrial preparation was kept on ice away from light and used for mitochondrial oxygen consumption measurements. The mitochondrial protein concentration was determined according to Bradford [60] using a bovine serum albumin (BSA) standard, and considering the protein content of the mitochondrial assay buffer.

Mitochondrial respiration measurements were conducted in two thermostatted perspex respiration chambers of $3 \mathrm{ml}$ volume (World Precision Instruments, Inc., USA), equipped with an adjustable stopper and ports for the injection of metabolites and inhibitors and one for insertion of a TX micro-optode (PreSens - Precision Sensing $\mathrm{GmbH}$, Germany), used for fluoroptic measurement of $\mathrm{PO}_{2}$. The oxygen traces were recorded with a PowerLab recording unit and Chart v5.5.6 software (ADInstruments $\mathrm{GmbH}$, Germany). Mitochondrial respiration rates were converted to $\mathrm{nmol}_{2}{ }^{*} \mathrm{mg}$ extracted mitochondrial protein ${ }^{-1 *} \mathrm{~min}^{-1}$.

Measurements were carried out in assay buffer with a final volume of $1200 \mu \mathrm{l}$ with mitochondrial concentrations adjusted to about $3 \mathrm{mg}$ mitochondrial protein per $\mathrm{ml}$, at 0 , 6 , and $12 \pm 0.1^{\circ} \mathrm{C}$, respectively. Chamber temperature was maintained with a thermostat (LAUDA, Germany). Respiration was recorded and malate and pyruvate added to a final concentration of $1.3 \mathrm{mM}$ and $1.6 \mathrm{mM}$, respectively, as substrates for complex I (state II), and ADP (final conc. $0.16 \mathrm{mM}$ ) was added to measure state III (max. slope). Then, $2 \mathrm{mM}$ succinate was added as complex II substrate and $0.16 \mathrm{mM}$ ADP for state III respiration.

\section{Enzyme assays}

Frozen liver tissue was ground into powder by mortar and pestle under liquid nitrogen and homogenized in a glass homogenizer in 9 vol. buffer containing $20 \mathrm{mmol} \mathrm{l}^{-1}$ Tris- $\mathrm{HCl}, 1 \mathrm{mmol} \mathrm{l}^{-1}$ EDTA, 0.1\% Triton X-100, pH 7.4, and afterwards with an Ultra Turrax (Silent Crusher M (Heidolph Instruments, Germany), followed by $10 \mathrm{~min}$ centrifugation at $1,000 \mathrm{~g}$ at $4^{\circ} \mathrm{C}$. Cytochrome $c$ oxidase (COX) activity was determined according to a protocol modified from Moyes et al. [61] in buffer containing $20 \mathrm{mmol} \mathrm{l}^{-1}$ Tris-HCl, $0.05 \%$ Tween 20 and $0.057 \mathrm{mM}$ reduced cytochrome $c$ at $\mathrm{pH}$ 8.0. The decrease in extinction at $\lambda=550 \mathrm{~nm}$ through oxidation of cytochrome $c$ $\left(\varepsilon_{550}=19.1 \mathrm{~mol}^{-1} \mathrm{~cm}^{2}\right)$ was monitored in a thermostatted spectrophotometer (Beckman, Fullerton, CA, USA) at 0, 
6 and $12^{\circ} \mathrm{C}$. Protein concentration of the tissue extract was determined according to Bradford [60], enzyme activity is given in $\mu \mathrm{mol}^{*} \mathrm{mg}$ protein ${ }^{-1 *} \mathrm{~min}^{-1}$.

\section{Acid-base parameters Intracellular acid-base variables}

Measurement of $\mathrm{pH}_{\mathrm{i}}$ was carried out according to the homogenization technique developed by Pörtner [47]. A solution of $1 \mathrm{mM}$ nitrilotriacetic acid (NTA) and 160 $\mathrm{mM}$ potassium fluoride (KF) was used to keep the NTA concentration as low as possible. $\mathrm{CCO}_{2}$ was measured by gas chromatography (6890N Network GC System, Agilent Technologies), total $\mathrm{CO}_{2}$ in cell water was calculated according to Pörtner [47], assuming a fractional tissue water content of 0.78 [62]. Intracellular acid-base parameters were calculated using the following, modified Henderson-Hasselbalch equation.

$$
\begin{aligned}
& \mathrm{PCO}_{2}=\mathrm{C}_{\mathrm{CO} 2} \mathrm{x}\left(10^{\mathrm{pH}-\mathrm{pK}^{\prime \prime \prime}} \mathrm{x} \alpha+\alpha\right)^{-1} \\
& {\left[\mathrm{HCO}_{3}{ }^{-}\right]=\mathrm{CCO}_{2}-\alpha \mathrm{PCO}_{2}}
\end{aligned}
$$

Intracellular $\mathrm{pK}$ "' and $\alpha$ (solubility) values were evaluated according to Heisler [62] using $\left[\mathrm{Na}^{+}\right]=0.02 \mathrm{M},[\mathrm{M}]=0.21$ $\mathrm{mol} \mathrm{l}^{-1}, \mathrm{I}=0.12 \mathrm{~mol} \mathrm{l}^{-1}$ and [Protein] $=220 \mathrm{~g} \mathrm{l}^{-1}$ [47].

The tissue buffer values $\beta_{\mathrm{NB}}$ for liver and muscle were adopted from Van Dijk et al. [63].

\section{Extracellular values}

Blood plasma $\mathrm{pH}$ (extracellular $\mathrm{pH}, \mathrm{pH}_{\mathrm{e}}$ ) was measured immediately after sampling at the acclimation temperature with a pH meter (WTW 340i, WTW, Germany. Electrode: InLab $^{\circledR}$ Viscous, Mettler Toledo GmbH, Germany). The $\mathrm{pH}$ meter was calibrated daily with NBS buffers (WTW, Germany). Measurements were carried out in a closed microcentrifuge tube $(0.5 \mathrm{ml})$ to minimize contact with environmental air. Plasma total $\mathrm{CO}_{2}\left(\mathrm{C}_{\mathrm{CO} 2}\right)$ was measured after centrifugation by means of a carbon dioxide analyser (Corning 965, CIBA, Corning Diagnostics, England). Blood carbonate chemistry was calculated using the modified Henderson-Hasselbalch equation (eqn. 3 and 4). Values for the $\mathrm{CO}_{2}$-solubility coefficient $\alpha$ and the negative logarithm of the dissociation constant K'" were calculated after Heisler [62]. The values required for the calculation (ionic strength, protein concentration, $\mathrm{Na}^{+}$ concentration) were adopted from Egginton [64].

\section{Blood non-bicarbonate buffer value $\left(\beta_{N B}\right)$}

After heparinization of the blood $(100 \mathrm{U} / \mathrm{ml})$, the $\beta_{\mathrm{NB}}$ capacity was determined at $0.5^{\circ} \mathrm{C}$ in a thermostatted tonometer. $1.5 \mathrm{ml}$ of whole blood was equilibrated with different $\mathrm{PCO}_{2}\left(1 \mathrm{kPa}, 2 \mathrm{kPa}, 3 \mathrm{kPa} \mathrm{CO}_{2}\right)$ for 1 hour before $\mathrm{pH}$ (electrode: $\mathrm{InLab}^{\circledR}$ Viscous, Mettler Toledo $\mathrm{GmbH}$, Germany) and $\mathrm{C}_{\mathrm{CO} 2}$ were measured (gas chromatography:
6890N Network GC System, Agilent Technologies). The $\beta_{\mathrm{NB}}$ capacity $\left(-\Delta\left[\mathrm{HCO}_{3}^{-}\right] / \Delta \mathrm{pH}\right)$ was determined with values for $\Delta\left[\mathrm{HCO}_{3}^{-}\right]$calculated after equation 4 .

\section{Data analysis and statistics}

The temperature coefficient $\mathrm{Q}_{10}$ was calculated for routine metabolic rate and mitochondrial respiration (state III) according to the formula

$$
\mathrm{Q}_{10}=\left(\mathrm{MO}_{2(2)} / \mathrm{MO}_{2(1)}\right)^{10 /\left(\mathrm{T}_{2}-\mathrm{T}_{1}\right)}
$$

The respiratory control ratio (RCR) was calculated as the ratio between mitochondrial state III (complex I and II) and state IV (after ADP depletion) respiration.

All data were tested for outliers at the 95\% significance level using Nalimov's test [65] as well as for normality (Kolmogorov-Smirnov) and homogeneity of variance. Differences in routine metabolic rate, mitochondrial oxygen consumption and COX activity at the assay temperatures $0,6,12^{\circ} \mathrm{C}$, blood and intracellular acid-base variables, between the different acclimation groups were tested using unpaired, two-tailed t-tests and one-way analysis of variance (ANOVA, with Tukey post-hoc test). $p \leq 0.05$ was considered the significance threshold. All data are presented as means \pm standard error of the mean (SEM).

\section{Results}

\section{Animal condition and haematological parameters}

The relative liver weights (hepatosomatic indices, HSI), condition factors, haematocrits, blood osmolarities and lactate levels, as well as the blood acid-base parameters determined for control and acclimated $N$. rossii, are summarized in Table 2. The HSI showed a nonsignificant tendency to decrease after warm-acclimation of $N$. rossii in both the normocapnic $\left(7^{\circ} \mathrm{C}, 0.04 \mathrm{kPa} \mathrm{CO}\right.$ ) and the hypercapnic $\left(7^{\circ} \mathrm{C}, 0.2 \mathrm{kPa} \mathrm{CO}_{2}\right)$ groups. Acclimation to higher $\mathrm{PCO}_{2}$ at $1^{\circ} \mathrm{C}$ had no significant effect on the HSI. The condition factor of $N$. rossii, indicating nutritional status, was significantly decreased in the warm hypercapnic group. The haematocrit of $N$. rossii displayed no acclimation effect. Lactate concentrations in the blood, on average, remained below detection limit $\left(<0.8 \mathrm{mmol}^{*} \mathrm{l}^{-1}\right)$. Only in the cold hypercapnic group, lactate was slightly elevated to $1.13 \pm 0.11 \mathrm{mmol}^{*} \mathrm{l}^{-1}$. The blood osmolarity in $N$. rossii was significantly reduced in all warm and hypercapnia acclimated animals.

\section{Routine metabolic rate}

$N$. rossii exposed to acute warming $\left(7^{\circ} \mathrm{C}\right)$ showed significantly increased, two-fold higher RMR compared to the control group $\left(1.35 \pm 0.20\right.$ (control at $1^{\circ} \mathrm{C}, n=5$ ) vs. $2.71 \pm 0.41$ (acutely warmed to $7^{\circ} \mathrm{C}, n=3$ ) mmo$\left.1 \mathrm{O}_{2}{ }^{*} \mathrm{~kg}^{-1 *} \mathrm{~h}^{-1}\right)$, as displayed in Figure 1 . 
Table 2 Animal condition (HSI= hepatosomatic index, CF=condition factor), and blood parameters of the Antarctic fish N. rossii

\begin{tabular}{|c|c|c|c|c|c|c|c|}
\hline \multicolumn{2}{|c|}{ Acclimation } & \multirow[b]{2}{*}{$\mathbf{N}$} & \multirow[b]{2}{*}{ HSI } & \multirow[b]{2}{*}{$\mathrm{CF}$} & \multirow[b]{2}{*}{ Haematocrit } & \multirow[b]{2}{*}{ Lactate } & \multirow[b]{2}{*}{ Osmolarity } \\
\hline $\mathrm{T}$ & $\mathrm{PCO}_{2}$ & & & & & & \\
\hline$\overline{\left({ }^{\circ} \mathrm{C}\right)}$ & $(\mathrm{kPa})$ & & & & & $\left(\left.\mathrm{mmol}^{*}\right|^{-1}\right)$ & $\left(\left.m O s m^{*}\right|^{-1}\right)$ \\
\hline 1 & 0.04 & 9 & $1.83 \pm 0.33$ & $1.69 \pm 0.03$ & $28 \pm 2$ & $<0.8$ & $436.8 \pm 9.5$ \\
\hline 7 & 0.04 & 9 & $0.91 \pm 0.04^{*}$ & $1.57 \pm 0.07$ & $29 \pm 2$ & $<0.8$ & $373.8 \pm 15.7^{*}$ \\
\hline 1 & 0.2 & 5 & $1.22 \pm 0.12$ & $1.59 \pm 0.03$ & $29 \pm 1$ & $1.13 \pm 0.11$ & $399.5 \pm 13.3$ \\
\hline 7 & 0.2 & 10 & $0.81 \pm 0.06^{*}$ & $1.5 \pm 0.03^{*}$ & $31 \pm 1$ & $<0.8$ & $390.0 \pm 8.6^{*}$ \\
\hline
\end{tabular}

Control: $1^{\circ} \mathrm{C}, 0.04 \mathrm{kPa} \mathrm{CO}$; warm normocapnia: $7^{\circ} \mathrm{C}, 0.04 \mathrm{kPa} \mathrm{CO}$; cold hypercapnia: $1^{\circ} \mathrm{C}, 0.2 \mathrm{kPa} \mathrm{CO}_{2} ;$ warm hypercapnia: $7^{\circ} \mathrm{C}, 0.2 \mathrm{kPa} \mathrm{CO}_{2}$ All values are given as means $\pm \mathrm{SEM}$. * indicate a significant difference to control conditions ( $t$-test, $p \leq 0.05)$.

Oxygen consumption in the control group and the long-term warm and/ or hypercapnia acclimated N. rossii was measured at the end of the 4-weeks acclimation period. In comparison to the control group, the RMR of the long-term warm and normocapnia acclimated fish was significantly increased at $7^{\circ} \mathrm{C} \quad(2.23 \pm 0.16$ $\mathrm{mmol} \mathrm{O}_{2}{ }^{*} \mathrm{~kg}^{-1 * \mathrm{~h}^{-1}}(n=5), \mathrm{Q}_{10}$ of 2.38). However, after long-term warm acclimation RMR was significantly lower compared to that of the acutely warmed $N$. rossii at $7^{\circ} \mathrm{C}\left(\mathrm{Q}_{10}\right.$ of 3.2). RMR after cold hypercapnia acclimation $\left(1.28 \pm 0.10 \mathrm{mmol} \quad \mathrm{O}_{2}{ }^{*} \mathrm{~kg}^{-1 *} \mathrm{~h}^{-1}, n=6\right)$ was similar to that in control animals. Warm hypercapnia acclimation resulted in a significantly increased RMR $\left(2.49 \pm 0.22 \mathrm{mmol} \mathrm{O}_{2}{ }^{*} \mathrm{~kg}^{-1 * \mathrm{~h}^{-1}}, n=5\right.$, measured at $\left.7^{\circ} \mathrm{C}\right)$ compared to the control group measured at $1^{\circ} \mathrm{C}$. No significant difference in RMR was found between the long-term warm normocapnic and the warm hypercapnic groups.

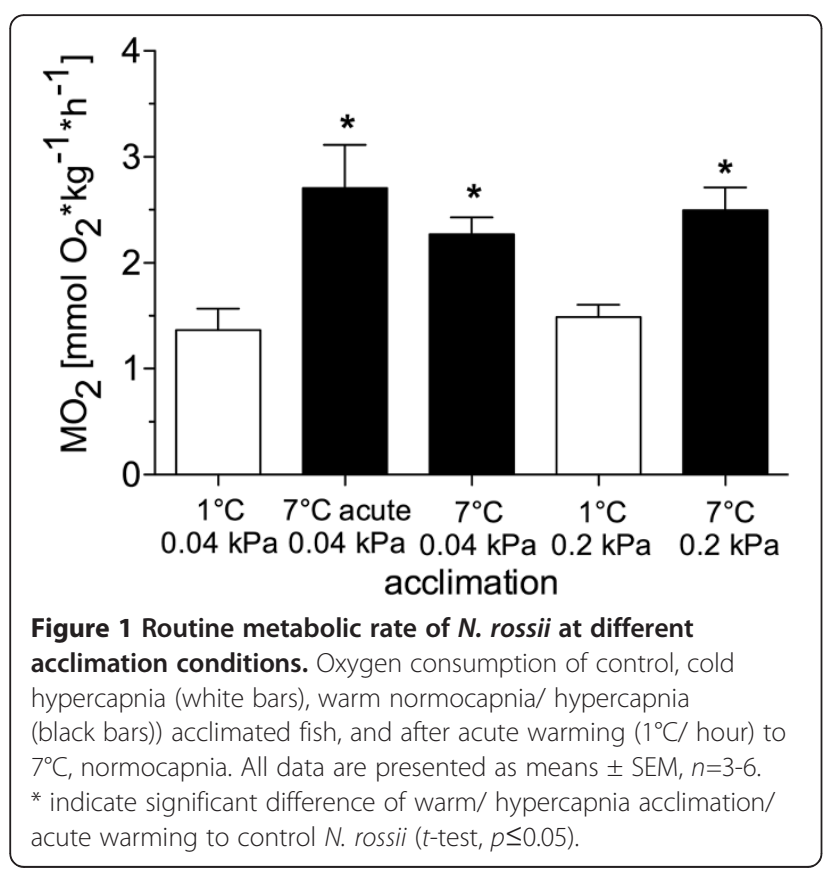

Mitochondrial respiration, respiratory control ratio (RCR) and mitochondrial $\mathbf{Q}_{10}$

Liver mitochondrial state III respiration increased significantly when assay temperature was changed acutely from $0^{\circ} \mathrm{C}\left(2.79 \pm 0.18 \mathrm{nmol} \mathrm{O}_{2}{ }^{*} \mathrm{mg}^{*} \mathrm{~min}^{-1}\right)$ to $6^{\circ} \mathrm{C}(5.64 \pm 1.17 \mathrm{nmol}$ $\left.\mathrm{O}_{2}{ }^{*} \mathrm{mg}^{*} \mathrm{~min}^{-1}\right)$ and $12^{\circ} \mathrm{C}\left(7.55 \pm 1.49 \mathrm{nmol} \mathrm{O}_{2}{ }^{*} \mathrm{mg}^{*} \mathrm{~min}^{-1}\right)$ in the control group $(n=10)$, with similar rates in the warm normocapnic fish $\left(n=5 ; 0^{\circ} \mathrm{C}: 3.86 \pm 0.19 ; 6^{\circ} \mathrm{C}: 5.53 \pm 0.34\right.$; $\left.12^{\circ} \mathrm{C}: 6.55 \pm 1.62 \mathrm{nmol} \mathrm{O}_{2}{ }^{* *} \mathrm{mg}^{* *} \mathrm{~min}^{-1}\right)$. In cold hypercapnia $\left(n=9 ; 0^{\circ} \mathrm{C}: 1.73 \pm 0.42 ; 6^{\circ} \mathrm{C}: 2.65 \pm 0.30 ; 12^{\circ} \mathrm{C}: 4.49 \pm 0.94 \mathrm{nmol}\right.$ $\mathrm{O}_{2}{ }^{*} \mathrm{mg}^{*} \mathrm{~min}^{-1}$ ) and warm hypercapnia acclimated fish, state III respiration was significantly increased only at $12^{\circ} \mathrm{C}$ $\left(n=9 ; 0^{\circ} \mathrm{C}: 1.95 \pm 0.36 ; 6^{\circ} \mathrm{C}: 3.89 \pm 0.85 ; 12^{\circ} \mathrm{C}: 6.40 \pm 1.50 \mathrm{nmol}\right.$ $\mathrm{O}_{2}{ }^{*} \mathrm{mg}^{*} \mathrm{~min}^{-1}$ ) (Figure 2). In the cold hypercapnic animals, state III respiration was significantly reduced (at $6^{\circ} \mathrm{C}$ and $12^{\circ} \mathrm{C}$ in the assay) compared to the control group.

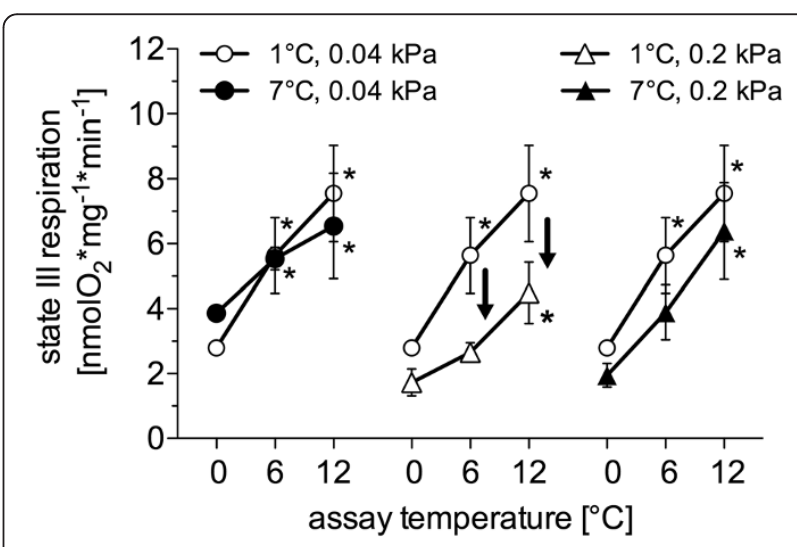

Figure 2 State III respiration rate in liver mitochondria of $N$. rossii. State 3 respiration was measured in the presence of malate, pyruvate, succinate and ADP at the respective assay temperature $\left(0^{\circ} \mathrm{C}, 6^{\circ} \mathrm{C}, 12^{\circ} \mathrm{C}\right)$ in four different long-term acclimated groups; open circles: $1^{\circ} \mathrm{C}, 0.04 \mathrm{kPa} \mathrm{CO}$ (control); filled circles: $7^{\circ} \mathrm{C}, 0.04 \mathrm{kPa} \mathrm{CO}$ (warm normocapnic); open triangles: $1^{\circ} \mathrm{C} 0.2 \mathrm{kPa} \mathrm{CO}_{2}$ (cold hypercapnic); filled triangles: $7^{\circ} \mathrm{C} 0.2 \mathrm{kPa} \mathrm{CO}$ (warm hypercapnic). * indicate significantly higher mitochondrial respiration than at $0^{\circ} \mathrm{C}$ assay. $\downarrow$ depicts significantly reduced mitochondrial respiration in comparison to control acclimation $\left(1^{\circ} \mathrm{C}, 0.04 \mathrm{kPa} \mathrm{CO}_{2}\right)$. All data are presented as means \pm SEM, $n=5-10$. 
Within each experimental group, RCR did not vary significantly between the different assay temperatures $\left(0,6,12^{\circ} \mathrm{C}\right)$, whereas between the experimental groups the mean RCR of the 0,6 and $12^{\circ} \mathrm{C}$ assays were significantly reduced in both cold and warm hypercapnia acclimated animals compared to the control group (Table 3). There was no difference in the $\mathrm{Q}_{10}$ values for mitochondrial state III respiration in the acute assay temperature range from $0-12^{\circ} \mathrm{C}$ between the different acclimation groups.

\section{Enzyme activities}

In the warm hypercapnic group, COX activities in liver were decreased compared to the control at all temperatures. A similar trend was apparent in the cold hypercapnic animals, but only significant in the assay at $12^{\circ} \mathrm{C}$ (Figure 3). COX activities in liver extracts of the warm normocapnic group were significantly higher than in the control group at the $6^{\circ} \mathrm{C}$ assay.

\section{Acid-base parameters of $\mathrm{N}$. rossii Intracellular}

The $\mathrm{pH}_{\mathrm{i}}$ of muscle tissue of the control $N$. rossii was $7.33 \pm 0.07(n=3)$ (Table 4). The highest, though not significant deviation from the control group was found in the warm normocapnic animals $(0.08 \mathrm{pH}$ units lower). Liver $\mathrm{pH}_{\mathrm{i}}$ was lower than the respective muscle $\mathrm{pH}_{\mathrm{i}}$ in all treatments, control $\mathrm{pH}_{\mathrm{i}}$ of liver tissue was $7.08 \pm 0.03(n=3)$. In

Table 3 Respiratory control ratio (RCR; for each assay temperature and as mean RCR over all three assay temperatures at the respective acclimation) and $\mathbf{Q}_{10}$ of N. rossii (control: $1^{\circ} \mathrm{C}, 0.04 \mathrm{kPa} \mathrm{CO}{ }_{2}$; warm normocapnia: $7^{\circ} \mathrm{C}, 0.04 \mathrm{kPa} \mathrm{CO}$; cold hypercapnia: $1^{\circ} \mathrm{C}, 0.2 \mathrm{kPa} \mathrm{CO}_{2}$; warm hypercapnia: $7^{\circ} \mathrm{C}, 0.2 \mathrm{kPa} \mathrm{CO}_{2}$ )

\begin{tabular}{|c|c|c|c|c|c|c|}
\hline \multicolumn{2}{|l|}{ Acclimation } & \multirow[b]{2}{*}{$\begin{array}{l}\text { Assay temp. } \\
{\left[{ }^{\circ} \mathrm{C}\right]}\end{array}$} & \multicolumn{2}{|l|}{$\mathrm{RCR}$} & \multirow{2}{*}{$\frac{Q_{10}}{0-12^{\circ} \mathrm{C}}$} & \multirow[b]{2}{*}{$\mathrm{N}$} \\
\hline $\begin{array}{l}\text { Temperature } \\
{\left[{ }^{\circ} \mathrm{C}\right]} \\
\end{array}$ & $\begin{array}{l}\mathrm{PCO}_{2} \\
{[\mathrm{kPa}]}\end{array}$ & & $\mathrm{Cl}+\mathrm{Cll}$ & mean & & \\
\hline \multirow[t]{3}{*}{1} & 0.04 & 0 & $4.9 \pm 0,4$ & $4.6 \pm 0.8$ & $1.6 \pm 0.3$ & 5 \\
\hline & & 6 & $5.2 \pm 0.8$ & & & 5 \\
\hline & & 12 & $3.6 \pm 0.2$ & & & 5 \\
\hline \multirow[t]{3}{*}{7} & 0.04 & 0 & $5.0 \pm 0.6$ & $4.0 \pm 1.0$ & $1.8 \pm 0.3$ & 5 \\
\hline & & 6 & $3.9 \pm 0.6$ & & & 5 \\
\hline & & 12 & $3.0 \pm 0.9$ & & & 5 \\
\hline \multirow[t]{3}{*}{1} & 0.2 & 0 & $4.6 \pm 0.6$ & $3.8 \pm 0.8^{*}$ & $2.4 \pm 0.4$ & 10 \\
\hline & & 6 & $4.0 \pm 0.6$ & & & 10 \\
\hline & & 12 & $3.0 \pm 0.4$ & & & 10 \\
\hline \multirow[t]{3}{*}{7} & 0.2 & 0 & $4.2 \pm 0.6$ & $3.5 \pm 0.6^{*}$ & $2.1 \pm 0.3$ & 9 \\
\hline & & 6 & $3.4 \pm 0.3$ & & & 9 \\
\hline & & 12 & $2.9 \pm 0.2$ & & & 9 \\
\hline
\end{tabular}

* indicates a significantly different RCR compared to control N. rossi.

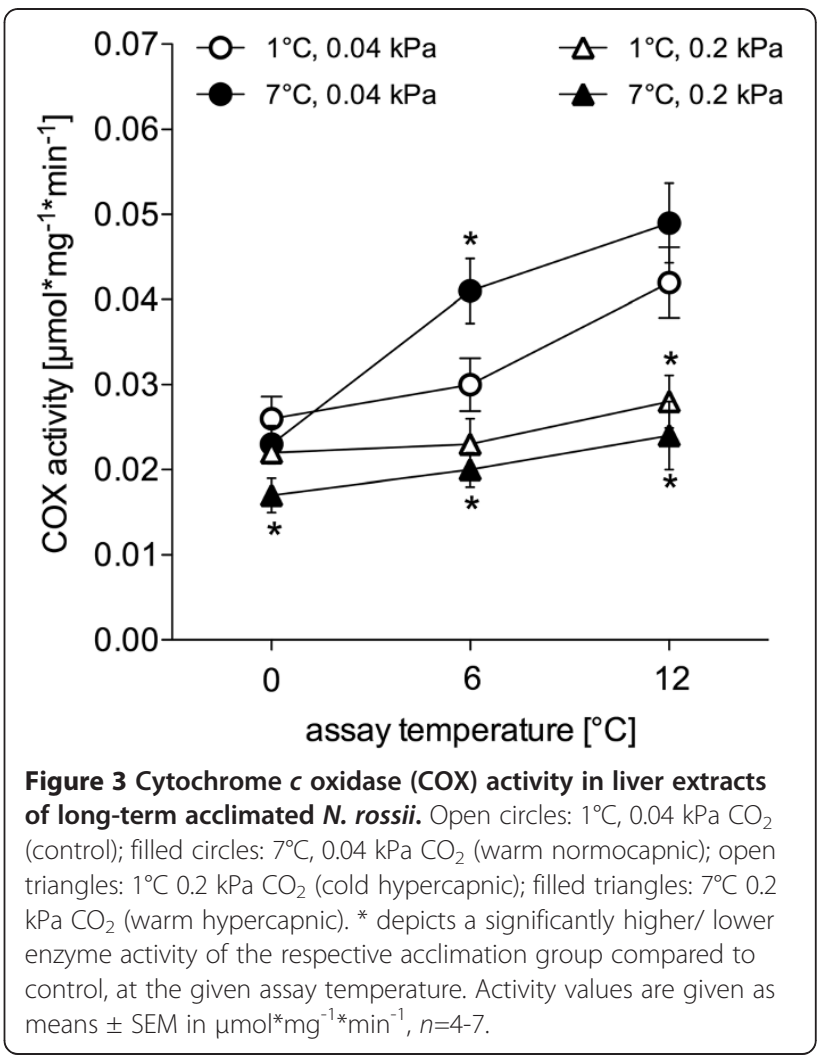

parallel, liver $\mathrm{PCO}_{2}$ in all acclimation groups was significantly higher than muscle $P \mathrm{CO}_{2}$. All acclimation groups showed muscle tissue $\left[\mathrm{HCO}_{3}^{-}\right]$elevated above controls $\left(\left[\mathrm{HCO}_{3}^{-}\right]=3.99 \pm 0.41 \mathrm{mM}\right)$, up to $6.72 \pm 0.66 \mathrm{mM}(n=5)$ in cold hypercapnic specimens and $6.85 \pm 0.37 \mathrm{mM}(n=10)$ in warm hypercapnic individuals.

Liver $\left[\mathrm{HCO}_{3}^{-}\right]$was generally higher than in muscle samples. $\left[\mathrm{HCO}_{3}^{-}\right]$in liver under control conditions $(9.21 \pm 0.37 \mathrm{mM}, n=3)$ was slightly lower than in the cold hypercapnic group $(10.11 \pm 1.19 \mathrm{mM}, n=5)$ and the warm hypercapnic group $(10.35 \pm 0.72 \mathrm{mM}, n=7)$. These data have to be considered with caution, as due to sample shortage (most liver tissue was needed for isolation of mitochondria) there was only one liver sample available for $\mathrm{pH}_{\mathrm{i}}$ estimation in the warm normocapnic group, however, with a value similar to those in the warm hypercapnic group $(n=7)$.

Visualisation of the intracellular acid-base parameters in a pH-bicarbonate diagram (Figure 4) illustrates that in liver tissue, changes in acid-base status of the cold hypercapnic group changed in parallel to the assumed non-bicarbonate buffer line of controls; only in the warm normocapnic $N$. rossii was the resulting value located distinctly below the non-bicarbonate buffer line of controls. In white muscle, the $\mathrm{CO}_{2}$ induced acidosis in both cold and warm hypercapnic groups was compensated for by a significant rise in $\left[\mathrm{HCO}_{3}^{-}\right]$, resulting in 
Table 4 Intracellular and extracellular $\mathrm{pH}\left(\mathrm{pH}_{\mathrm{i} / \mathrm{e}}\right)$ and acid-base parameters in white muscle/ liver tissue homogenates and blood, respectively, from $N$. rossii. Control: $1^{\circ} \mathrm{C}, 0.04 \mathrm{kPa} \mathrm{CO}_{2} ;$ warm normocapnia: $7^{\circ} \mathrm{C}, 0.04 \mathrm{kPa} \mathrm{CO}_{2} ; \mathrm{cold}^{\circ}$ hypercapnia: $1^{\circ} \mathrm{C}, 0.2 \mathrm{kPa} \mathrm{CO}_{2}$; warm hypercapnia: $7^{\circ} \mathrm{C}, 0.2 \mathrm{kPa} \mathrm{CO}_{2}$

\begin{tabular}{|c|c|c|c|c|c|c|c|c|c|c|c|c|c|}
\hline \multicolumn{2}{|c|}{ Acclimation } & \multicolumn{4}{|c|}{ White muscle homogenate } & \multicolumn{4}{|c|}{ Liver homogenate } & \multicolumn{4}{|c|}{ Blood acid-base parameters } \\
\hline $\begin{array}{l}\mathrm{T} \\
\left({ }^{\circ} \mathrm{C}\right)\end{array}$ & $\begin{array}{l}\mathrm{PCO}_{2} \\
(\mathrm{kPa})\end{array}$ & $\mathrm{N}$ & $\begin{array}{l}\mathrm{PCO}_{2} \\
(\mathrm{kPa})\end{array}$ & $\begin{array}{l}{\left[\mathrm{HCO}_{3}^{-}\right]} \\
\left(\left.\mathrm{mmol}^{*-1}\right|^{-1}\right)\end{array}$ & $\mathrm{pHi}$ & $\mathrm{N}$ & $\begin{array}{l}\mathrm{PCO}_{2} \\
(\mathrm{kPa})\end{array}$ & $\begin{array}{l}{\left[\mathrm{HCO}_{3}^{-}\right]} \\
\left(\mathrm{mmol}^{\left.*\right|^{-1}}\right)\end{array}$ & $\mathrm{pHi}$ & $\mathrm{N}$ & $\begin{array}{l}\mathrm{PCO}_{2} \\
(\mathrm{kPa})\end{array}$ & $\begin{array}{l}{\left[\mathrm{HCO}_{3}^{-}\right]} \\
\left.\left(\mathrm{mmol}^{*-1}\right)^{-1}\right)\end{array}$ & $\mathrm{pHe}$ \\
\hline 1 & 0.04 & 3 & $0.640 \pm 0.126$ & $3.994 \pm 0.410$ & $7.325 \pm 0.065$ & 3 & $2.555 \pm 0.270$ & $9.213 \pm 0.379$ & $7.080 \pm 0.027$ & 9 & $1.18 \pm 0.19$ & $8.05 \pm 0.56$ & $7.438 \pm 0.055$ \\
\hline 7 & 0.04 & 5 & $1.071 \pm 0.123$ & $5.294 \pm 0.335$ & $7.242 \pm 0.037$ & 1 & 3.616 & 8.020 & 6.890 & 9 & $1.16 \pm 0.05$ & $6.31 \pm 0.28^{\mathrm{a}, \mathrm{b}}$ & $7.315 \pm 0.045^{b}$ \\
\hline 1 & 0.2 & 5 & $0.936 \pm 0.117$ & $6.724 \pm 0.664^{\mathrm{a}}$ & $7.383 \pm 0.027$ & 5 & $3.031 \pm 0.484$ & $10.107 \pm 1.197$ & $7.053 \pm 0.066$ & 5 & $1.46 \pm 0.09$ & $11.28 \pm 0.32^{\mathrm{a}, \mathrm{b}, \mathrm{c}}$ & $7.508 \pm 0.028$ \\
\hline 7 & 0.2 & 10 & $1.296 \pm 0.167$ & $6.849 \pm 0.373^{\mathrm{a}}$ & $7.290 \pm 0.038$ & 7 & $4.495 \pm 0.521$ & $10.347 \pm 0.724$ & $6.920 \pm 0.039$ & 10 & $1.41 \pm 0.11$ & $10.08 \pm 0.57^{\mathrm{a}}$ & $7.507 \pm 0.037$ \\
\hline
\end{tabular}

Data are presented as means \pm SEM. Superscript letters indicate following significant differences: $a-$ sign. different to control conditions, $b$ - sign. different to temperature $\& \mathrm{CO}_{2}$ acclimation. c -sign. different to temperature acclimation ( $t$-test, ANOVA, $p \leq 0.05$ ).

values close to the $\mathrm{PCO}_{2}$ isobar of $\sim 0.95$ and $1.15 \mathrm{kPa}$ $\mathrm{CO}_{2}$, respectively.

\section{Extracellular}

Cold hypercapnia acclimation did not significantly affect $\mathrm{pH}_{\mathrm{e}}$, which was $7.44 \pm 0.06(n=9)$ under control conditions (Table 4). $\mathrm{pH}_{\mathrm{e}}$ was significantly higher in the warm hypercapnic group $(7.51 \pm 0.04, n=10)$ than in the warm normocapnic $(7.32 \pm 0.05, n=9)$ group. None of the acclimations significantly affected extracellular $P \mathrm{CO}_{2}$, however, changes in bicarbonate result as a consequence of $\mathrm{CO}_{2}$ enrichment from 1.2 to $1.4 \mathrm{kPa}$ in warm and from 1.2 to $1.5 \mathrm{kPa}$ in cold acclimated animals. Cold hypercapnia acclimation was in fact associated with a significant increase in bicarbonate levels $\left(\left[\mathrm{HCO}_{3}^{-}\right]\right.$control: 8.05 $\mathrm{mmol}^{*} \mathrm{l}^{-1}$, cold hypercapnic $\left.11.28 \mathrm{mmol}^{*-1} \mathrm{l}^{-1}\right)$. In contrast, blood $\left[\mathrm{HCO}_{3}^{-}\right]$of the warm normocapnic animals was significantly decreased $\left(6.31 \mathrm{mmol}^{*} \mathrm{l}^{-1}\right)$. When displayed in a $\mathrm{pH}$-bicarbonate diagram (Figure 5), together with the blood buffer line $\beta_{\mathrm{NB}}$ of $30.3 \mathrm{mmol}^{*} \mathrm{pH}^{-1 * \mathrm{l}^{-1}}$ which we measured for $N$. rossii at $0^{\circ} \mathrm{C}$, it becomes obvious that long-term hypercapnia acclimation involves a marked accumulation of $\left[\mathrm{HCO}_{3}^{-}\right]$, resulting in elevated steady state levels.

\section{Discussion}

\section{Aerobic energy metabolism}

During acute warming, the RMR of $N$. rossii increased as a result of rising metabolic rate with a $\mathrm{Q}_{10}$ of 3.1 (Figure 1), which is consistent with previous studies on acute thermal responses of different Antarctic fish species [11,26,66,67]. A part of the increase in metabolic rate can likely be attributed to the high costs of the low capacity cardio-vascular system to meet the increasing metabolic oxygen demand, which has been demonstrated for Antarctic eelpouts $[13,68]$. Due to limited cardiac scope and increased friction of the vascular system at high blood flow rates, sufficient oxygen delivery at warm temperatures result in a relatively

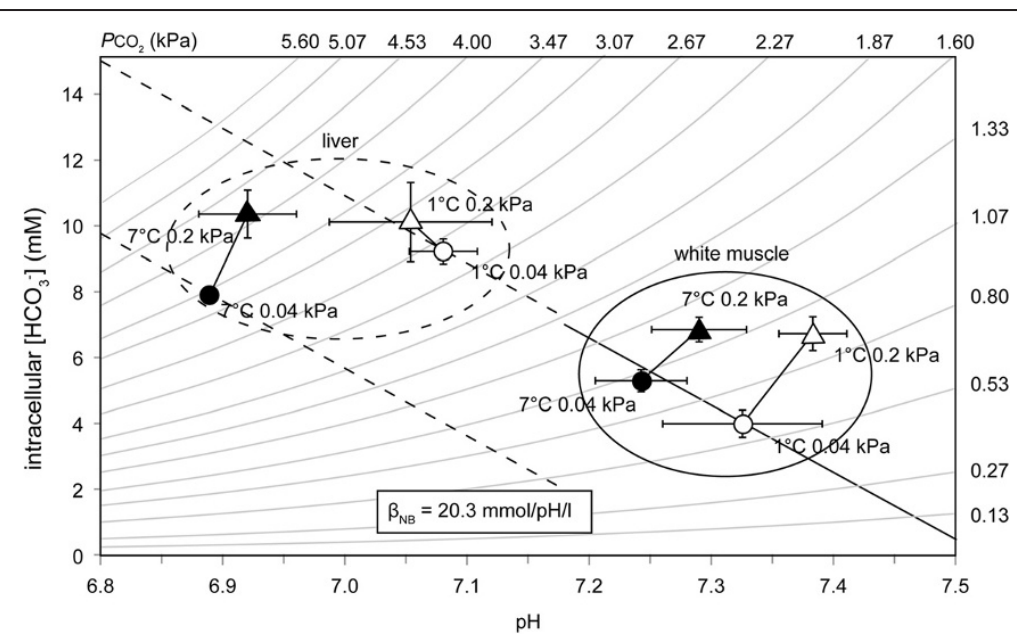

Figure $4 \mathrm{pH}_{\mathrm{i}} /\left[\mathrm{HCO}_{3}^{-}\right]$(Davenport) diagram of intracellular $\mathrm{pH}\left(\mathrm{pH}_{\mathrm{i}}\right)$ and acid-base parameters. Values of liver and white muscle homogenates of control $\left(1^{\circ} \mathrm{C}, 0.04 \mathrm{kPa} \mathrm{CO}\right)$ and warm normocapnia $\left(7^{\circ} \mathrm{C} 0.04 \mathrm{kPa} \mathrm{CO}_{2}\right)$, cold hypercapnia $\left(1^{\circ} \mathrm{C}, 0.2 \mathrm{kPa} \mathrm{CO}_{2}\right)$ and warm hypercapnia $\left(7^{\circ} \mathrm{C}, 0.2 \mathrm{kPa} \mathrm{CO}\right.$ ) acclimated $\mathrm{N}$. rossii (c.f. Table 4). All data are given as means $\pm \mathrm{SEM}, n=1-7$. The solid line marks the nonbicarbonate buffer line $\left(\beta_{\mathrm{NB}}\right)$ for white muscle, the dashed line for liver. $\beta_{\mathrm{NB}}$ value was adopted from VanDijk et al. [63] for the Antarctic eelpout $P$. brachycephalum. 


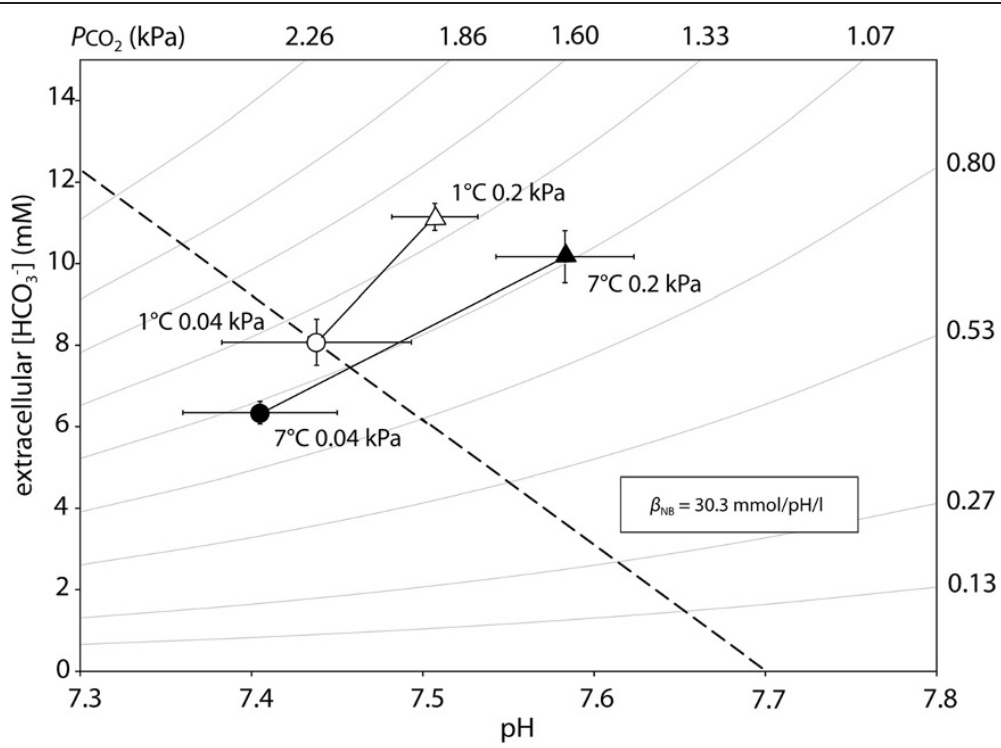

Figure $5 \mathrm{pH}_{\mathrm{e}} /\left[\mathrm{HCO}_{3}^{-}\right]$(Davenport) diagram of the extracellular acid-base variables. Acid-base parameters are depicted for control $\left(1^{\circ} \mathrm{C} 0.04\right.$ $\left.\mathrm{kPa} \mathrm{CO}_{2}\right)$ and warm normocapnia $\left(7^{\circ} \mathrm{C} 0.04 \mathrm{kPa} \mathrm{CO}_{2}\right)$, cold hypercapnia $\left(1^{\circ} \mathrm{C}, 0.2 \mathrm{kPa} \mathrm{CO}_{2}\right)$ and warm hypercapnia $\left(7^{\circ} \mathrm{C}, 0.2 \mathrm{kPa} \mathrm{CO}_{2}\right)$ acclimated $\mathrm{N}$. rossii (c.f. Table 4). The dashed line marks the in vitro non-bicarbonate buffer line $\left(\beta_{\mathrm{NB}}\right)$, curved lines represent $P \mathrm{CO}_{2}$ isopleths. All data are presented as means \pm SEM, $n=5-10$.

higher workload for the heart. A compensation of cardiac scope during long-term acclimation may alleviate this to some extent, contributing to a lower RMR and $\mathrm{Q}_{10}$ of 2.3 after warm acclimation (Figure 1), which indicate a partial, incomplete compensation of RMR in N. rossii (type 3 after Precht [69]). The same effect occurred in the long-term warm hypercapnic acclimated $N$. rossii, providing evidence that the partially compensated RMR in the warm hypercapnic fish was exclusively induced by temperature and not by elevated $\mathrm{PCO}_{2}$.

Following long-term acclimation of $N$. rossii to higher temperatures and $\mathrm{PCO}_{2}$, animal condition displayed pronounced changes. While control values of HSI and condition factor were within the same range reported recently for $N$. rossii caught in Potter Cove, King George Island [28], they were reduced in warm and hypercapnia acclimated $N$. rossii, although the fish were fed to satiation (control HSI 1.83, condition factor 1.69, warm hypercapnic HSI 0.81 , condition factor 1.5 ; see Table 2 ). This reduction may be attributed to a reduced aerobic scope caused by elevated RMR (see above) at the high acclimation temperatures chosen.

The fact that the warm-acclimated fish could not completely compensate their RMR to a level comparable to the control animals could indicate beginning limitations in the circulatory system of $N$. rossii and in oxygen supply to tissues. As a result, the aerobic scope for the SDA response (specific dynamic action) [70,71] might be limited at warmer temperatures. Consequently, fish may not be capable to ingest sufficient food over time to meet the required energy demand and to sustain basal metabolic rate, even if fed ad libitum. To maintain RMR elevated in warmer water, energy stores such as liver fat may be mobilized [72], resulting in the observed lower HSI and condition factor (see above).

The paradigm that Antarctic fish have limited acclimation capacity because of their thermal specialization has been challenged by several studies reporting compensatory adjustments of whole animal respiration, cardiovascular response and blood viscosity at elevated temperatures $[11,16,24,66,73]$. Most of these studies focused on the cryo-pelagic fish $P$. borchgrevinki or on several Trematomus species. In $N$. coriiceps, the congener of $N$. rossii, an acclimation-induced shift in critical thermal maxima $\left(\mathrm{CT}_{\max }\right)$ was observed, but the increase was small compared to the shifts observed in other Antarctic species (e.g. P. brachycephalum, Gobionotothen gibberifrons, T. pennellii and T. hansoni, see Bilyk and DeVries [66] for further details), further corroborating our conclusions for $N$. rossii.

In general, the measurement of RMR provides a suitable indicator of a species' thermal tolerance, as limits in oxygen consumption can reflect the onset of whole animal oxygen limitation and associated limitations in circulatory capacity [74]. Nevertheless, the precise determination of aerobic limits under increased temperature and $\mathrm{PCO}_{2}$ benefits from the combined study of several indicators including enzyme and mitochondrial capacities, the limiting factors in ATP supply.

The mitochondrial state III respiration of the control group rose continuously with rising experimental assay 
temperatures of 0,6 and $12^{\circ} \mathrm{C}$. The RCR values were stable between 0 and $12^{\circ} \mathrm{C}$ (see Table 3), indicating efficient mitochondrial coupling up to $12^{\circ} \mathrm{C}$. A decrease in $\mathrm{Q}_{10}$ from 2.4 (range $0-6^{\circ} \mathrm{C}$ ) to 1.6 (range $6-12^{\circ} \mathrm{C}$ ), indicates that state III respiration became less responsive to temperature at higher assay temperatures, and led to a similar decrease in mitochondrial scope as reported for $N$. rossii [28] and Lepidonotothen nudifrons [12] beyond $9^{\circ} \mathrm{C}$.

In contrast to the elevation of RMR in the warm normocapnia acclimated $N$. rossii, maximum mitochondrial respiration rates were not significantly higher than in the control group (Figure 2). This was reflected in similar values of RCR (control: 4.6 \pm 0.8 , warm normocapnia: 4.0 \pm 1.0 ) and $Q_{10}$ between these two groups over the whole range of assay temperatures $\left(\mathrm{Q}_{10}\right.$ from 0 to $12^{\circ} \mathrm{C}$, control: 1.6; warm normocapnia: 1.8 ) (see Table 3 ). Only the trend towards a reduced thermal slope of mitochondrial state III respiration of the warm normocapnic fish (linear regression analysis of state III respiration from 0 to $12^{\circ} \mathrm{C}$ assay temperature; warm normocapnic: slope 0.22 [(nmol O$\left.\left.{ }_{2}^{*} \mathrm{~min}^{-1 *} \mathrm{mg}^{-1}\right)^{*} 1^{\circ} \mathrm{C}\right]$, control group: 0.39) could point towards a beginning compensation of mitochondrial respiration. The partial (type III) compensation at the whole animal level (RMR, Figure 1) could therefore originate at the mitochondrial level, possibly underpinning relevant adjustments of the cardiovascular system.

Interestingly, cold hypercapnia acclimation led to significantly reduced state III respiration at acute assay temperatures of $6^{\circ} \mathrm{C}$ and $12^{\circ} \mathrm{C}$ compared to the control group, accompanied by a significantly reduced mean RCR over the whole range of assay temperatures (Table 2). Similarly, state III respiration was depressed in the warm hypercapnia acclimated $N$. rossii, below that of the control group (Figure 2), and showed significantly reduced RCRs, indicating a clear effect of elevated ambient $\mathrm{PCO}_{2}$ on mitochondrial metabolism. This effect did not translate into a change in whole animal RMR but may reflect a decrease in tissue and whole animal aerobic and functional scope. In contrast, a downregulation in resting aerobic metabolic rate occurred under acute hypercapnic acidosis in muscle tissue of the invertebrate Sipunculus nudus, reflecting a reduction in ATP consuming processes of maintenance metabolism (e.g. anabolic/ catabolic protein metabolism) [75,76]. Such energy savings might also occur in fishes and affect proteins involved in mitochondrial respiration (e.g. reduced citrate synthase activities in hypercapnia acclimated Sparus aurata [40]), thereby causing a lower state III respiration. Since state IV respiration remained unchanged after cold or warm hypercapnia acclimation (data not shown), the reduced coupling capacities were likely caused by the reduced state III respiration (per mg mitochondrial protein) and not by increased proton leak rates. The reduced COX activities (per mg cellular protein)
(Figure 3) in the liver of both cold and warm hypercapnia acclimated $N$. rossii support this hypothesis and are in line with the projected changes in protein activity, including possible modifications in the mitochondrial membrane.

The differences observed at the mitochondrial level only partially reflected the whole animal level (see Figure 1), specifically in that the mitochondrial studies exclusively concentrated on liver tissue, which only constitutes a fraction of whole animal metabolism. A possible whole organism consequence of such capacity limits in mitochondrial metabolism under conditions of elevated energy demand (e.g. activity, reproduction) may be shifts in metabolic pathways [40] and a decrease in aerobic scope under long-term elevated $\mathrm{PCO}_{2}$. Further alterations may include a reduction in growth or behavioural capacities under long-term increased $\mathrm{PCO}_{2}$, as observed in coral reef fish (Amphiprion percula \& Neopomacentrus azysron) [77-79].

\section{Acid-base regulation}

The changes in mitochondrial capacities may be related to shifts in extra- and particularly intracellular acid-base status. The liver $\mathrm{pH}_{\mathrm{i}}$ in control $N$. rossii of this study $\left(\mathrm{pH}_{\mathrm{i}}\right.$ 7.08, Table 4) were similar to values recorded for the eelpout $Z$. viviparus $\left(\mathrm{pH}_{\mathrm{i}} 7.06\right.$, [63]). The $\mathrm{pH}_{\mathrm{i}}$ values of the white muscle samples (e.g. control group; $\mathrm{pH}_{\mathrm{i}}$ 7.325) were close to values reported for Antarctic and non-Antarctic fish in other studies (e.g. G. morhua 7.34, [80]; P. brachycephalum 7.42-7.43 [81], Harpagifer antarcticus $\mathrm{pH}_{\mathrm{i}} 7.36$ at $1^{\circ} \mathrm{C}$ [49], $7.33 \mathrm{~N}$. coriiceps [82]). In the warm normocapnia acclimated group, white muscle values followed the $\alpha$-stat pattern [83], with a lowering of $\mathrm{pH}$ with increasing temperature by $-0.014 \mathrm{pH}$ units $/{ }^{\circ} \mathrm{C}$. Such a rise in body temperature also caused a linear drop of $\mathrm{pH}_{\mathrm{i}}$ in white muscle of the North Sea eelpout $Z$. viviparus $\left(-0.016 \mathrm{pH}\right.$ units $\left./{ }^{\circ} \mathrm{C}\right)$ [63]. The illustration of intracellular acid-base parameters in the $\mathrm{pH}$-bicarbonate diagram (Figure 4) emphasizes a defence of liver $\mathrm{pH}_{\mathrm{i}}$ by the non-bicarbonate buffer system (such as proteins or amino acid residues) in the cold hypercapnia acclimated fish, in similar ways as recorded e.g. for G. morhua [80] or freshwater catfish Liposarcus pardalis [43].

In the liver of the warm hypercapnia acclimated $N$. rossii (Figure 4), $\mathrm{pH}_{\mathrm{i}}$ was compensated by intracellular $\mathrm{HCO}_{3}^{-}$accumulation, in parallel to the findings in the blood $\left(\mathrm{pH}_{\mathrm{e}}\right)$ and muscle $\mathrm{pH}_{\mathrm{i}}$. This compensation of chronically increased $\mathrm{PCO}_{2}$ of both cold and warm groups may have contributed to the observed shifts in metabolic steady state towards slightly alkaline $\mathrm{pH}$ values. The long-term reaction to acute changes in acidbase status may include shifts in the use of metabolic substrates by favouring oxidative decarboxylation of dicarboxylic acids (malate, glutamate/ aspartate) [75,84]. These reactions could help to reduce the elevated 
proton load under chronic elevated $P \mathrm{CO}_{2}$, thereby playing an important role in the buffering of changes in the acid-base status. Nevertheless, such modifications appear to be insufficient to maintain full mitochondrial capacities in $N$. rossii, paralleled by the observed reduced COX activities and RCR of the cold/ warm hypercapnic mitochondria.

During long-term elevated ambient $P \mathrm{CO}_{2}, \mathrm{CO}_{2}$ enters the mitochondria by diffusion, yielding an increase in proton and $\left[\mathrm{HCO}_{3}^{-}\right]$levels. Taking into account the $\mathrm{pH}$ and total $\mathrm{CO}_{2}$ gradient maintained between mitochondria and the cytoplasm under control conditions, liver mitochondrial $\left[\mathrm{HCO}_{3}^{-}\right]$of the warm hypercapnic animals were up to $10 \mathrm{mmol} / \mathrm{l}$ higher than in the warm normocapnic group (or $4 \mathrm{mmol} / \mathrm{l}$ in the cold hypercapnic group compared to their controls); calculated after [47,85]. Earlier studies of the acute effects of alkaline $\mathrm{pH}$ and increased $\left[\mathrm{HCO}_{3}^{-}\right]$on liver mitochondria revealed inhibitions in the TCA-cycle [86], thereby lowering mitochondrial respiratory capacities and their capacity to supply ATP. In trout (O. mykiss) hepatocytes, acutely increased $\left[\mathrm{HCO}_{3}^{-}\right]$at $1 \mathrm{kPa} \mathrm{PCO}_{2}$ also depresses mitochondrial metabolism via interruptions in the TCA-cycle, possibly caused by alterations in citrate and phosphate transport [87].

Intracellular acid-base regulation is supported by the respective adjustments in extracellular acid-base status, e.g. the accumulation of extracellular bicarbonate during compensation for the respiratory acidosis [88]. The same shift in 'set points' towards alkaline values observed at the intracellular level occurred in the blood. In contrast to other $\mathrm{pH}_{\mathrm{e}}$ values recorded for temperate marine fish (e.g. cod 7.95 [80], flounder 7.78 [89], seabream 7.65 [40]), the extracellular $\mathrm{pH}$ of $N$. rossii was quite low in the present study (pH 7.44 in the control group). A study by Egginton [90] revealed a low blood $\mathrm{pH}$ of 7.5 for $N$. coriiceps directly after capture, which increased to 7.7 over 96 hours during recovery from landing stress. In cannulated $N$. coriiceps $\mathrm{pH}_{\mathrm{e}}$ increased from 7.5 to 8.0 during recovery, a value consistent with the blood $\mathrm{pH}$ of 8.01 measured for N. rossii by Egginton et al. [64]. pH values measured in the present study may be lower than these values due to 'grab and stab' effects, as the cannulation of animals was experimentally not possibly. Nevertheless, these handling effects should have affected measurements in all experimental groups in similar ways and thereby still allow for comparison between the different acclimation groups.

As expected for marine teleost fish (e.g. Conger conger [91], G. morhua [80] or Sparus aurata [40]), the acute acidosis evoked by higher environmental $P \mathrm{CO}_{2}$ was compensated for by a significant increase in plasma $\left[\mathrm{HCO}_{3}^{-}\right]$in both the cold and warm hypercapnic groups. The depiction in the $\mathrm{pH}$-bicarbonate diagram (Figure 5) shows that the increase in plasma $\left[\mathrm{HCO}_{3}^{-}\right]$cannot solely be attributed to extracellular non-bicarbonate buffering. Instead, combined acid-base parameters were positioned above the non-bicarbonate buffer line, likely due to the involvement of proton equivalent ion transfer processes [92]. Although the pattern of compensation is similar for many teleost fish, the $\left[\mathrm{HCO}_{3}^{-}\right]$reached differ between species: e.g. levels reached $22 \mathrm{mM}$ in C. conger [91], and $32 \mathrm{mM}$ in cod, respectively [80] when exposed to $1 \mathrm{kPa} \mathrm{CO}$. The exposure to a moderate $\mathrm{PCO}_{2}$ of 0.2 $\mathrm{kPa}$ led to lower but still significantly elevated $\left[\mathrm{HCO}_{3}^{-}\right]$ of $11.3 \mathrm{mM}$ in cold hypercapnic N. rossii.

The compensation of higher ambient $P \mathrm{CO}_{2}$ via elevated $\left[\mathrm{HCO}_{3}^{-}\right]_{\mathrm{e}}$ and $\left[\mathrm{HCO}_{3}^{-}\right]_{\mathrm{i}}$ can lead to an increase in ATP demand for ion exchanging processes to maintain $\left[\mathrm{HCO}_{3}^{-}\right]$at this higher level, as it was reported for longterm hypercapnia acclimated eelpout (Z. viviparus) [93]. The reaction to this constantly higher ATP demand could be a shift in energy budget with reduced ATP consuming processes, e.g. protein turnover or anabolism [93]. This new metabolic equilibrium under increased metabolic demands for acid-base regulation could result in shifted 'set points', as we observed in the warm or cold hypercapnia acclimated $N$. rossii, with $\mathrm{pH}$ shifted towards alkaline values and thus a constant, slight metabolic alkalosis in both groups.

Both temperature and hypercapnia influence blood parameters in Antarctic fish, which has been demonstrated for blood osmolarity after thermal acclimation in notothenioids [94]. This explains the observed decreased serum osmolarities in our warm acclimated animals. The unaffected osmolarities in cold hypercapnia acclimated $N$. rossii are in line with earlier findings by Larsen et al. [80] for cod (G. morhua) exposed to $1 \mathrm{kPa} \mathrm{CO}_{2}$. Although we observed hypercapnia induced changes in ion regulation, the higher $\left[\mathrm{HCO}_{3}^{-}\right]_{\mathrm{e}}$ in the blood are too small to significantly alter total osmolarity. Hence, the changes in osmolarity can exclusively be attributed to long-term warm acclimation.

The haematocrit levels of $N$. rossii were unaffected by warm and/ or hypercapnia acclimation, and within the range reported for its sympatric sister species $N$. coriiceps $[26,95]$ (Table 2). While acute warming causes an elevation of haematocrit in red-blooded notothenioids [26], longterm warm acclimation leaves haematocrit levels constant, consistent with results from other studies on Antarctic notothenioids [94]. Thus, the oxygen carrying capacities of the blood of warm and/ or hypercapnia acclimated N. rossii do not seem to be limiting under these conditions.

It has been assumed that the extracellular nonbicarbonate buffering is mostly accomplished by proteins in the blood [96], and thus strongly depends on haematocrit [97], which varies greatly between fish species, also among Antarctic fish species [26,28,98,99]. The 
haematocrit levels measured in $N$. rossii (28-31, see Table 2) thus result in high blood $\beta_{\mathrm{NB}}$ values (30.3 $\mathrm{mmol} / \mathrm{l} \mathrm{pH})$. Similarly, the red-blooded Antarctic fish Dissostichus mawsoni and $P$. borchgrevinki showed higher $\beta_{\mathrm{NB}}$ values ( 28 and $18 \mathrm{mmol} / \mathrm{l} \mathrm{pH}$, respectively) than the haemoglobinless icefish Pagetopsis macropterus $\left(\beta_{\mathrm{NB}} \sim 3 \mathrm{mmol} / \mathrm{l} \mathrm{pH}\right)[100]$.

Some possible limitations in oxygen availability may have occurred at the intracellular level in the warm normocapnia acclimated fish, where liver $\mathrm{pH}_{\mathrm{i}}$ was lower than in the control group. This $\mathrm{pH}$ difference cannot be exclusively attributed to $\alpha$-stat regulation [83], as $\mathrm{pH}_{\mathrm{i}}$ changed by $-0.032 \mathrm{pH}$ units $/{ }^{\circ} \mathrm{C}$. Possibly, the high acclimation temperature of $7^{\circ} \mathrm{C}$ led to limiting oxygen supply to the liver tissue as a consequence of elevated metabolic demand, resulting in a slight contribution of anaerobic metabolism and thereby lactate production, thus shifting the $\mathrm{pH}_{\mathrm{i}}$ of the warm normocapnic group to acidic values. Nevertheless, other tissues with lower metabolic loads than liver, such as white muscle, may still be able to metabolise anaerobic end products to some degree, allowing the animals to survive at these warmer temperatures (4-6 weeks acclimation time in this study).

We did, however, not observe elevated lactate values in the blood of warm normocapnic/ hypercapnic fish, and the generally low lactate values of $N$. rossii were similar to those measured in $N$. rossii and $N$. coriiceps earlier $[28,101]$. Only in the cold hypercapnia acclimated animals, lactate levels were slightly elevated, but are likely the result of minor handling stress and do not originate from a beginning anaerobic metabolism in the liver, as they are still close to the levels of $1 \mathrm{mM}$ reported for $N$. coriiceps under natural conditions $[26,90]$.

A higher ATP demand under conditions of elevated temperature in combination with an intracellular acidosis might shift or even impair liver functionality over a longer time-scale in the warm-acclimated animals (normocapnia/ hypercapnia), which could relate to the reduced HSI in the animals of the present study (see Table 2).

\section{Conclusion}

This study investigated the thermal plasticity and acclimation abilities to higher temperature and $\mathrm{PCO}_{2}$ levels of the Antarctic teleost fish $N$. rossii, by studying metabolic responses at different organisation levels (whole animal, blood, cellular and mitochondrial level).

At the whole animal level, our findings reveal partial compensation of RMR in the long-term warm normocapnia and hypercapnia acclimated fish in comparison to acute warm $\left(7^{\circ} \mathrm{C}\right)$ exposed $N$. rossii. Long-term acclimation to $0.2 \mathrm{kPa} \mathrm{CO}$ had no effect on RMR.

In the mitochondria, we observed only limited compensation of state III respiration following normocapnic warm acclimation. In contrast, both warm and cold hypercapnia acclimation led to reduced mitochondrial capacities, possibly mediated by changes in the TCAcycle or the whole mitochondria, as indicated by reduced enzyme capacities.

In cold and warm hypercapnia acclimated fish, we observed shifts in the 'set points' of acid-base regulation to more alkaline values at both extra- and intracellular levels, mediated by actively accumulated $\left[\mathrm{HCO}_{3}^{-}\right]$. These shifts may be involved in the hypercapnia-induced changes in cellular and mitochondrial energy demand. During long-term hypercapnia, shifts towards oxidative decarboxylation processes may maintain new acid-base equilibria. As the reduced mitochondrial capacities of the cold and warm hypercapnia acclimated fish were not visible in whole animal respiration, $N$. rossii might be limited in energy supply and aerobic scope for e.g. activity, growth and reproduction.

In the context of other data available for other highAntarctic notothenioids [16,73], our data suggest that among the notothenioids the cold-adapted $N$. rossii will have only a moderate scope for acclimation and tolerance towards ocean acidification and warming of the Southern Ocean. At the chosen temperature of warm acclimation $\left(7^{\circ} \mathrm{C}\right)$, the liver function of $N$. rossii may shift or become disturbed, thereby likely reducing whole animal performance over longer time-scales.

\section{Competing interests}

The authors declare that they have no competing interests.

\section{Authors' contributions}

AS and FCM designed the study, carried out the animal capture, acclimation, mitochondrial respiration experiments and extracellular acid-base determination and drafted the manuscript. AS performed the data analyses and interpretation. SB carried out the intracellular acid-base determination and contributed to writing the manuscript. EL performed the enzyme measurements. KM participated in the coordination of the study and contributed to revising the manuscript. HOP participated in the study design and substantially contributed to writing the manuscript. All authors read and approved the final version of the manuscript

\section{Acknowledgements}

This work was supported by the Deutsche Forschungsgemeinschaft DFG grant PO 278/13-1 to AS, HOP and FCM, and a ERASMUS scholarship to EL. We wish to thank the crew of the Jubany Base (Carlini) on King George Island for their valuable technical support.

\section{Author details}

${ }^{1}$ Alfred Wegener Institute for Polar and Marine Research, Integrative Ecophysiology, Am Handelshafen 12, D-27570 Bremerhaven, Germany.

${ }^{2}$ University of Trieste, Department of Life Science, via Giorgieri 1, Trieste, Italy.

Received: 12 September 2012 Accepted: 16 October 2012

Published: 18 October 2012

\section{References}

1. Ferron FA, Simones JC, Aquino FE, Setzer AW: Air temperature series for King George Island, Antarcitca. Pesquisa Ant Brasil 2004, 4:155-169.

2. Cook AJ, Fox AJ, Vaughan DG, Ferrigno JG: Retreating Glacier Fronts on the Antarctic Peninsula over the Past Half-Century. Science 2005, 308:541-544. 
3. Turner J, Colwell SR, Marshall GJ, Lachlan-Cope TA, Carleton AM, Jones PD, Lagun V, Reid PA, lagovkina S: Antarctic climate change during the last 50 years. Int J Climatol 2005, 25:279-294

4. Meredith PM, King CJ: Rapid climate change in the ocean west of the Antarctic Peninsula during the second half of the 20th century. Washington, DC, USA: American Geophysical Union; 2005.

5. Turner J, Lachlan-Cope TA, Colwell S, Marshall GJ, Connolley WM: Significant Warming of the Antarctic Winter Troposphere. Science 2006, 311:1914-1917.

6. Clarke A, Murphy EJ, Meredith MP, King JC, Peck LS, Barnes DKA, Smith RC: Climate change and the marine ecosystem of the western Antarctic Peninsula. Philos Trans R Soc Lond B Biol Sci 2007 362:149-166.

7. Sabine $C L$, Feely RA, Gruber N, Key RM, Lee K, Bullister JL, Wanninkhof R, Wong CS, Wallace DW, Tilbrook B, et al: The oceanic sink for anthropogenic $\mathrm{CO}_{2}$. Science 2004, 305:367-371.

8. Caldeira K, Wickett ME: Anthropogenic carbon and ocean pH. Nature 2003, 425:365.

9. Caldeira K, Wickett ME: Ocean model predictions of chemistry changes from carbon dioxide emissions to the atmosphere and ocean: The ocean in a high-CO2 world. Washington, DC, USA: American Geophysical Union; 2005.

10. Cao L, Caldeira K: Atmospheric $\mathrm{CO}_{2}$ stabilization and ocean acidification. Geophys Res Lett 2008, 35:L19609.

11. Somero GN, DeVries AL: Temperature tolerance of some Antarctic fishes. Science 1967, 156:257-258.

12. Hardewig I, Peck LS, Pörtner HO: Thermal Sensitivity of Mitochondrial Function in the Antarctic Notothenioid Lepidonotothen nudifrons. J Comp Physiol B 1999, 169:597-604.

13. Mark FC, Bock C, Pörtner HO: Oxygen-limited thermal tolerance in Antarctic fish investigated by MRI and 31P-MRS. Am J Physiol Regul Integr Comp Physiol 2002, 283:R1254-R1262.

14. Peck LS: Prospects for survival in the Southern Ocean: vulnerability of benthic species to temperature change. Antarct Sci 2005, 17:497.

15. Verde $C$, Parisi $E$, di Prisco $G$ : The evolution of thermal adaptation in polar fish. Gene 2006, 385:137-145

16. Franklin CE, Davison W, Seebacher F: Antarctic fish can compensate for rising temperatures: thermal acclimation of cardiac performance in Pagothenia borchgrevinki. J Exp Biol 2007, 210:3068-3074

17. Pörtner HO: Climate-dependent evolution of Antarctic ectotherms: An integrative analysis. Deep Sea Res Part 2 Top Stud Oceanogr 2006, 53:1071-1104.

18. Pörtner $\mathrm{HO}$ : Climate change and temperature-dependent biogeography: oxygen limitation of thermal tolerance in animals. Naturwissenschaften 2001, 88:137-146.

19. Mark FC, Hirse T, Pörtner HO: Thermal sensitivity of cellular energy budgets in some Antarctic fish hepatocytes. Polar Biol 2005, 28:805-814.

20. Clarke A: What is cold adaptation and how should we measure it? Amer Zool 1991, 31:81-92.

21. Peck LS: Prospects for survival in the Southern Ocean: vulnerability of benthic species to temperature change. Antarctic Science-Institutional Subscription 2005, 17:497-508.

22. Pörtner HO, Lannig G: Oxygen and capacity limited thermal tolerance. In Fish Physiology, Vol 27: Hypoxia. Edited by Richards JG, Farrell AP, Brauner C. Burlington: Academic; 2009:143-191.

23. Lowe CJ, Davison W: Thermal sensitivity of scope for activity in Pagothenia borchgrevinki, a cryopelagic Antarctic nototheniid fish. Polar Biol 2006, 29:971-977.

24. Seebacher F, Davison W, Lowe CJ, Franklin CE: A falsification of the thermal specialization paradigm: compensation for elevated temperatures in Antarctic fishes. Biol Lett 2005, 1:151-154.

25. Podrabsky J, Somero G: Inducible heat tolerance in Antarctic notothenioid fishes. Polar Biol 2006, 30:39-43

26. Beers JM, Sidell BD: Thermal tolerance of Antarctic notothenioid fishes correlates with level of circulating hemoglobin. Physiol Biochem Zool 2011, 84:353-362.

27. Pörtner HO, Lucassen M, Storch D: Metabolic biochemistry: its role in thermal tolerance and in the capacities of physiological and ecological function. In The Physiology of Polar Fishes. Volume 21. Edited by Farrell AP, Steffensen JF. San Diego: Elsevier Academic Press; 2005:79-154 [Hoar WS, Randall DR, Farrell AP (Series Editor): Fish Physiology].
28. Mark FC, Lucassen M, Strobel A, Barrera-Oro E, Koschnick N, Zane L, Patarnello T, Pörtner HO, Papetti C: Mitochondrial Function in Antarctic Nototheniids with ND6 Translocation. PLoS One 2012, 7:e31860.

29. Pörtner HO, Hardewig I, Peck LS: Mitochondrial Function and Critical Temperature in the Antarctic Bivalve, Laternula elliptica. Comp Biochem Physiol A 1999, 124:179-189.

30. Heise K, Puntarulo S, Pörtner HO, Abele D: Production of reactive oxygen species by isolated mitochondria of the Antarctic bivalve Laternula elliptica (King and Broderip) under heat stress. Comp Biochem Physio/ C Toxicol Pharmacol 2003, 134:79-90.

31. Johnston I, Guderley H, Franklin C, Crockford T, Kamunde C: Are mitochondria subject to evolutionary temperature adaptation? J Exp Biol 1994, 195:293.

32. Urschel $\mathrm{M}, \mathrm{O}^{\prime}$ Brien $\mathrm{K}$ : Mitochondrial function in Antarctic notothenioid fishes that differ in the expression of oxygen-binding proteins. Polar Biol 2009, 32:1323-1330.

33. Lemieux H, Tardif J, Dutil J, Blier P: Thermal sensitivity of cardiac mitochondrial metabolism in an ectothermic species from a cold environment, Atlantic wolffish (Anarhichas lupus). J Exp Mar Bio Ecol 2010, 384:113-118.

34. Walther K, Sartoris F, Bock C, Pörtner HO: Impact of anthropogenic ocean acidification on thermal tolerance of the spider crab Hyas araneus. Biogeosciences Discussions 2009, 6:2837-2861.

35. Pörtner HO, Farrell AP: Ecology. Physiology and climate change. Science 2008, 322:690-692.

36. Metzger R, Sartoris F, Langenbuch M, Pörtner HO: Influence of elevated $\mathrm{CO}_{2}$ concentrations on thermal tolerance of the edible crab Cancer pagurus. J Therm Biol 2007, 32:144-151.

37. Foss A, Rųsnes B, Uiestad V: Graded environmental hypercapnia in juvenile spotted wolffish (Anarhichas minor Olafsen): effects on growth, food conversion efficiency and nephrocalcinosis. Aquaculture 2003, 220:607-617.

38. Fivelstad $S$, Olsen AB, Asgård $T$, Baeverfjord $G$, Rasmussen $T$, Vindheim $T$, Stefansson S: Long-term sublethal effects of carbon dioxide on Atlantic salmon smolts (Salmo salar L.): ion regulation, haematology, element composition, nephrocalcinosis and growth parameters. Aquaculture 2003, 215:301-319.

39. Melzner F, Gutowska M, Hu M, Stumpp M: Acid-base regulatory capacity and associated proton extrusion mechanisms in marine invertebrates: An overview. Comp Biochem Physiol A Mol Integr Physiol 2009, 153:S80.

40. Michaelidis B, Spring A, Pörtner HO: Effects of long-term acclimation to environmental hypercapnia on extracellular acid-base status and metabolic capacity in Mediterranean fish Sparus aurata. Mar Biol 2007, 150:1417-1429.

41. Pörtner $\mathrm{HO}$, Bock $\mathrm{C}$, Reipschläger $\mathrm{A}$ : Modulation of the cost of $\mathrm{pHi}$ regulation during metabolic depression: A P-31-NMR study in invertebrate (Sipunculus nudus) isolated muscle. J Exp Biol 2000, 203:2417-2428.

42. Bock C, Sartoris FJ, Wittig RM, Pörtner HO: Temperature-dependent pH regulation in stenothermal Antarctic and eurythermal temperate eelpout (Zoarcidae): an in-vivo NMR study. Polar Biol 2001, 24:869-874.

43. Brauner CJ, Wang T, Wang Y, Richards JG, Gonzalez RJ, Bernier NJ, Xi W, Patrick M, Val AL: Limited extracellular but complete intracellular acid-base regulation during short-term environmental hypercapnia in the armoured catfish, Liposarcus pardalis. J Exp Biol 2004, 207:3381-3390

44. Lannig G, Eilers S, Pörtner HO, Sokolova IM, Bock C: Impact of ocean acidification on energy metabolism of oyster, Crassostrea gigas - changes in metabolic pathways and thermal response. Mar Drugs 2010, 8:2318-2339.

45. Abe $\mathrm{H}$ : Role of histidine-related compounds as intracellular proton buffering constituents in vertebrate muscle. Biochemistry $\mathrm{c} / \mathrm{c}$ of Biokhimiya 2000, 65:757-765

46. Sartoris FJ, Bock C, Pörtner HO: Temperature-dependent pH regulation in eurythermal and stenothermal marine fish: an interspecies comparison using P-31-NMR. J Therm Biol 2003, 28:363-371.

47. Pörtner HO: Determination of Intracellular Buffer Values After Metabolic Inhibition by Fluoride and Nitrilotriacetic Acid. Respir Physiol 1990, 81:275-288. 
48. Young S, Egginton S: Allometry of skeletal muscle fine structure allows maintenance of aerobic capacity during ontogenetic growth. J Exp Biol 2009, 212:3564-3575

49. Moerland TS, Egginton S: Intracellular $\mathrm{pH}$ of muscle and temperature: insight from in vivo ${ }^{31} \mathrm{P}$ NMR measurements in a stenothermal Antarctic teleost (Harpagifer antarcticus). J Therm Bio/1998, 23:275-282.

50. Sosinski JSK: Biomass estimate of commercial fish on the shelf of South Georgia by the swept area method. Bull Sea Fish Inst 1987, 5-6:8-14

51. Duhamel G: Distribution and abundance of fish on the Kerguelen Island shelf. 1985th edition. Stockholm: Proc V Congr europ Ichthyol; 1987

52. Casaux R, Mazzotta A, Barrera-Oro E: Seasonal aspects of the biology and diet of nearshore nototheniid fish at Potter Cove, South Shetland Islands, Antarctica. Polar Biol 1990, 11:63-72.

53. Gon O, Heemstra P: Fishes of the Southern Ocean. Grahamstown, South Africa: J.L.B. Smith Institute for Ichthyology; 1990.

54. Everson I: Inshore fishes from the South Orkney and South Shetland Islands, the Antarctic Peninsula and South Georgia. Br Ant Surv Bull 1969, 19:89-96.

55. Schloss I, Ferreyra GA, González O, Atencio A, Fuentes V, Tosonotto G, Mercuri G, Sahade R, Tatián M, Abele D: Long term hydrographic conditions and climate trends. In The Potter Cove coastal ecosystem, Antarctica Synopsis of research performed 1999-2006 at the Dallmann Laboratony and Jubany Station, King George Island (Isla 25 de Mayo) Ber Polarforsch Meeres. Edited by Potter C, Wiencke C, Ferreyra G, Abele D, Marenssi S. 2008

56. Caldeira K, Wickett M: Ocean model predictions of chemistry changes from carbon dioxide emissions to the atmosphere and ocean. J Geophys Res 2005, 110:1-12

57. Pierrot D, Lewis E, Wallace DWR: MS Excel Program Developed for $\mathrm{CO}_{2}$ System Calculations. In Book MS Excel Program Developed for CO2 System Calculations. ORNL/CDIAC-105a editionth edition. City: Carbon Dioxide Information Analysis Center, Oak Ridge National Laboratory, U.S. Department of Energy; 2006

58. Johnston IA, Clarke A, Ward P: Temperature and metabolic rate in sedentary fish from the Antarctic, North Sea and Indo-West Pacific Ocean. Mar Biol 1991, 109:191-195.

59. Ricker WE: Computation and interpretation of the biological statistics of fish populations. Bull Fish Res Board Can 1975, 191:382

60. Bradford $M$ : A rapid and sensitive method for the quantitation of microgram quantities of protein utilizing the principle of proteindye binding. Anal Biochem 1976, 72:248-254.

61. Moyes C, Mathieu-Costello O, Tsuchiya N, Filburn C, Hansford R: Mitochondrial biogenesis during cellular differentiation. Am J Physiol Cell Physiol 1997, 272:C1345.

62. Heisler N: Acid-base Regulation in Animals. Amsterdam: Elsevier Science Publisher B.V. (Biomedical Division); 1986

63. Van Dijk PL, Hardewig I, Pörtner HO: Temperature-dependent shift of $\mathrm{pHi}$ in fish white muscle: contributions of passive and active processes. Am J Physiol 1997, 272:R84-R89.

64. Egginton S, Taylor E, Wilson R, Johnston I, Moon T: Stress response in the Antarctic teleosts (Notothenia neglecta Nybelin and N. rossii Richardson). J Fish Biol 1991, 38:225-235.

65. Noack S: Statistische Auswertung von Menü-und Versuchsdaten mit Taschenrechner und Tischcomputer. Berlin-New York: De Gruyter; 1980.

66. Bilyk KT, DeVries AL: Heat tolerance and its plasticity in Antarctic fishes. Comp Biochem Physiol A Mol Integr Physiol 2011, 158:382-390

67. Vanella FA, Calvo J: Influence of temperature, habitat and body mass on routine metabolic rates of Subantarctic teleosts. Sci Mar 2005, 69:317-323.

68. Pörtner $\mathrm{HO}$, Mark FC, Bock C: Oxygen limited thermal tolerance in fish? Answers obtained by nuclear magnetic resonance techniques. Respir Physiol Neurobiol 2004, 141:243-260.

69. Precht H, Christophersen J, Hensel H, Larcher W: Temperature and life. Berlin, Heidelberg: Springer; 1973.

70. Fry F: The Effect of Environmental Factors on the Physiology of Fish. Fish Physiol 1971, 6:1-98.

71. Jobling M: The influences of feeding on the metabolic rate of fishes: a short review. J Fish Biol 1981, 18:385-400.

72. Lannig G, Storch D, Pörtner HO: Aerobic mitochondrial capacities in Antarctic and temperate eelpout (Zoarcidae) subjected to warm versus cold acclimation. Polar Biol 2005, 28:575-584.
73. Robinson E, Davison W: The Antarctic notothenioid fish Pagothenia borchgrevinki is thermally flexible: acclimation changes oxygen consumption. Polar Biol 2008, 31:317-326.

74. Melzner F, Bock C, Pörtner HO: Temperature-dependent oxygen extraction from the ventilatory current and the costs of ventilation in the cephalopod Sepia officinalis. J Comp Physio/ B 2006, 176:607-621.

75. Langenbuch M, Pörtner $\mathrm{HO}$ : Changes in metabolic rate and $\mathrm{N}$ excretion in the marine invertebrate Sipunculus nudus under conditions of environmental hypercapnia: identifying effective acid-base variables. J Exp Biol 2002, 205:1153-1160.

76. Langenbuch M, Bock C, Leibfritz D, Pörtner HO: Effects of environmental hypercapnia on animal physiology: A C-13 NMR study of protein synthesis rates in the marine invertebrate Sipunculus nudus. Comp Biochem Physiol A Mol Integr Physiol 2006, 144:479-484.

77. Munday PL, Dixson DL, McCormick MI, Meekan M, Ferrari MC, Chivers DP: Replenishment of fish populations is threatened by ocean acidification. Proc Natl Acad Sci U S A 2010, 107:12930-12934

78. Domenici P, Allan B, McCormick Ml, Munday PL: Elevated carbon dioxide affects behavioural lateralization in a coral reef fish. Biol Lett 2012, 8:78-81.

79. Nilsson GE, Dixson DL, Domenici P, McCormick MI, Sørensen C, Watson SA, Munday PL: Near-future carbon dioxide levels alter fish behaviour by interfering with neurotransmitter function. Nat Clim Chang 2012, 2(3):201-204.

80. Larsen BK, Pörtner HO, Jensen FB: Extra- and Intracellular Acid-base Balance and lonic Regulation in cod (Gadus Morhua) during Combined and Isolated Exposures to Hypercapnia and Copper. Mar Biol 1997, 128:337-346.

81. Van Dijk PLM, Tesch C, Hardewig I, Pörtner HO: Physiological disturbances at critically high temperatures: A comparison between stenothermal Antarctic and eurythermal temperate eelpouts (Zoarcidae). J Exp Biol 1999, 202:3611-3621.

82. Taylor S, Egginton S, Taylor E, Franklin C, Johnston I: Estimation of intracellular $\mathrm{pH}$ in muscle of fishes from different thermal environments. J Therm Biol 1999, 24:199-208.

83. Reeves RB: An imidazole alphastat hypothesis for vertebrate acid-base regulation: tissue carbon dioxide content and body temperature in bullfrogs. Respir Physiol 1972, 14:219-236.

84. Pörtner HO: Contributions of anaerobic metabolism to $\mathrm{pH}$ regulation in animal tissues: theory. J Exp Biol 1987, 131:69-87.

85. Pörtner HO, MacLatchy LM, Toews DP: Acid-base regulation in the toad Bufo marinus during environmental hypoxia. Respir Physiol 1991, 85:217-230.

86. Simpson DP: Regulation of renal citrate metabolism by bicarbonate ion and $\mathrm{pH}$ : observations in tissue slices and mitochondria. J Clin Invest 1967, 46:225.

87. Walsh PJ, Mommsen TP, Moon T, Perry S: Effects of acid-base variables on in vitro hepatic metabolism in rainbow trout. J Exp Biol 1988, 135:231-241.

88. Pörtner HO, Reipschläger A, Heisler N: Acid-base Regulation, Metabolism and Energetics in Sipunculus nudus as a Function of Ambient Carbon Dioxide Level. J Exp Biol 1998, 201:43-55.

89. Nonnotte G, Truchot JP: Time course of extracellular acid-base adjustments under hypo- or hyperosmotic conditions in the euryhaline fish Platichthys flesus. J Fish Biol 1990, 36:181-190.

90. Egginton S: Stress response in two Antarctic teleosts (Notothenia coriiceps Richardson and Chaenocephalus aceratus Lönnberg) following capture and surgery. J Comp Physiol B 1994, 164:482-491.

91. Toews D, Holeton G, Heisler N: Regulation of the acid-base status during environmental hypercapnia in the marine teleost fish Conger conger. J Exp Biol 1983, 107:9-20

92. Pörtner HO: Ecosystem effects of ocean acidification in times of ocean warming: a physiologist's view. Mar Ecol Prog Ser 2008, 373:203-217.

93. Deigweiher K, Koschnick N, Pörtner HO, Lucassen M: Acclimation of ion regulatory capacities in gills of marine fish under environmental hypercapnia. Am J Physiol Regul Integr Comp Physiol 2008, 295:R1660-R1670.

94. Hudson $H$, Brauer P, Scofield M, Petzel D. Effects of warm acclimation on serum osmolality, cortisol and hematocrit levels in the Antarctic fish, Trematomus bernacchii. Polar Biol 2008, 31:991-997.

95. Heise K, Estevez M, Puntarulo S, Galleano M, Nikinmaa M, Pörtner HO, Abele D: Effects of seasonal and latitudinal cold on oxidative stress 
parameters and activation of hypoxia inducible factor (HIF-1) in zoarcid fish. J Comp Physiol B 2007, 177:765-777.

96. Cameron JN: Acid-base homeostasis: past and present perspectives. Physiol Zool 1989, 62:845-865.

97. Wood CM, McDonald D, McMahon B: The influence of experimental anaemia on blood acid-base regulation in vivo and in vitro in the starry flounder (Platichthys stellatus) and the rainbow trout (Salmo gairdneri). J Exp Biol 1982, 96:221.

98. Smit G, Hattingh J, Burger A: Haematological assessment of the effects of the anaesthetic MS 222 in natural and neutralized form in three freshwater fish species: interspecies differences. J Fish Biol 1979, 15:633-643.

99. Kunzmann A: Blood Physiology and Ecological Consequences in Weddell Sea Fishes (Antarctica) PhD. 1991

100. Wells RMG: Respiration of Antarctic fish from McMurdo Sound. Comp Biochem Physiol 1987, 88(A):417-424.

101. Egginton S: A comparison of the response to induced exercise in red- and white-blooded Antarctic fishes. J Comp Physiol B 1997, 167:129-134.

doi:10.1186/1742-9994-9-28

Cite this article as: Strobel et al: Metabolic shifts in the Antarctic fish

Notothenia rossii in response to rising temperature and $P \mathrm{CO}_{2}$. Frontiers in Zoology 2012 9:28.

\section{Submit your next manuscript to BioMed Central and take full advantage of:}

- Convenient online submission

- Thorough peer review

- No space constraints or color figure charges

- Immediate publication on acceptance

- Inclusion in PubMed, CAS, Scopus and Google Scholar

- Research which is freely available for redistribution 